\title{
Loss of Dnmt3a dependent methylation in inhibitory neurons impairs neural function through a mechanism that impacts Rett syndrome
}

Laura A. Lavery ${ }^{1,2}$, Kerstin Ure ${ }^{1,2, \#}$, Ying-Wooi Wan ${ }^{1,2}$, Chongyuan Luo ${ }^{3,4}$, Alexander J. Trostle ${ }^{1,5}$, Wei Wang $^{1,2}$, Joanna Lopez ${ }^{1,2}$, Jacinta Lucero ${ }^{6}$, Mark A. Durham ${ }^{7,8}$, Rosa Castanon ${ }^{3}$, Joseph R. Nery ${ }^{3}$, Zhandong Liu ${ }^{1,2,9}$, Margaret A. Goodel12,7,10,11, Joseph R. Ecker ${ }^{3,4}$, M. Margarita Behrens ${ }^{6,12}$, Huda Y. Zoghbi ${ }^{1,2,5,7,13,14, *}$

${ }^{1}$ Jan and Dan Duncan Neurological Research Institute at Texas Children's Hospital; Houston, TX, 77030, USA

${ }^{2}$ Department of Molecular and Human Genetics; Baylor College of Medicine; Houston, TX, 77030, USA

${ }^{3}$ Genomic Analysis Laboratory, The Salk Institute for Biological Studies; La Jolla, CA, 92037, USA.

${ }^{4}$ Howard Hughes Medical Institute, The Salk Institute for Biological Studies; La Jolla, CA, 92037, USA

${ }^{5}$ Department of Pediatrics; Baylor College of Medicine; Houston, TX, 77030, USA

${ }^{6}$ Computational Neurobiology Laboratory, The Salk Institute for Biological Studies; La Jolla, CA, 92037, USA

${ }^{7}$ Program in Developmental Biology; Baylor College of Medicine; Houston, TX, 77030, USA

${ }^{8}$ Medical Scientist Training Program; Baylor College of Medicine; Houston, TX, 77030, USA

${ }^{9}$ Graduate Program in Quantitative and Computational Biosciences, Baylor College of Medicine;

Houston, TX, 77030, USA

${ }^{10}$ Stem Cells and Regenerative Medicine Center, Baylor College of Medicine; Houston, TX, 77030, USA.

${ }^{11}$ Center for Cell and Gene Therapy, Baylor College of Medicine; Houston, TX, 77030, USA.

${ }^{12}$ Department of Psychiatry; University of California San Diego; La Jolla, CA 92093, USA

${ }^{13}$ Department of Neuroscience; Baylor College of Medicine; Houston, TX, 77030, USA

${ }^{14}$ Howard Hughes Medical Institute; Baylor College of Medicine; Houston, TX, 77030, USA

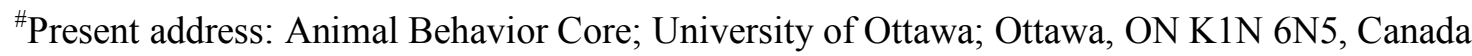

*Corresponding Author, Lead Contact. Email: hzoghbi@bcm.edu 


\begin{abstract}
Methylated cytosine is an effector of epigenetic gene regulation. In the mammalian brain, the DNA methyltransferase, Dnmt3a, is the sole "writer" of atypical non- $\mathrm{CpG}$ methylation $(\mathrm{mCH})$, and methyl $\mathrm{CpG}$ binding protein 2 (MeCP2) is the only known "reader" for $\mathrm{mCH}$. We set out to determine if $\mathrm{MeCP} 2$ is the sole reader for Dnmt3a dependent methylation by comparing mice lacking either Dnmt3a or MeCP2 in GABAergic inhibitory neurons. Loss of either the writer or the reader causes overlapping and distinct features from the behavioral to the molecular level. Loss of Dnmt3a results in global loss of $\mathrm{mCH}$ and a small subset of mCG sites resulting in more widespread transcriptional alterations and severe neurological dysfunction than seen upon MeCP2 loss. These data indicate that MeCP2 is responsible for reading part of the Dnmt3a dependent methylation in the brain. Importantly, the impact of MeCP2 on genes differentially expressed in both cKO models shows a strong dependence on $\mathrm{mCH}$, but not Dnmt3a dependent $\mathrm{mCG}$, consistent with $\mathrm{mCH}$ playing a central role in the pathogenesis of Rett Syndrome.
\end{abstract}

\title{
Keywords
}

Non-CpG methylation, Dnmt3a, MeCP2, inhibitory neuron, Rett syndrome 


\section{Introduction}

DNA methylation is a covalent epigenetic mark deposited mainly on the C5-position of naïve cytosine nucleotides in mammals. Although DNA methylation in mammals was described by Rollin Hotchkiss in 1948 (1), it took nearly thirty years to realize its function in the regulation of gene expression to shape fundamental biological processes including cell differentiation, genomic imprinting and genome stability $(2,3)$.

Today many features of the classic model for gene regulation by DNA methylation have proven more complex. Rather than static and solely repressive to gene expression, DNA methylation is functionally dynamic (4), and in some cases has been shown to activate gene expression (5-8) highlighting that context and protein factors that recognize methylated cytosine can alter the transcriptional outcome of this epigenetic mark.

It was also traditionally thought that DNA methylation in mammalian genomes could be found only at cytosines followed by guanine nucleotides ( $\mathrm{CpG}$ methylation, or $\mathrm{mCG})$, but it has become clear that cytosines in other contexts can also be methylated. This non-CpG methylation (also known as $\mathrm{mCH}$, where $\mathrm{H}$ equals $\mathrm{A}, \mathrm{C}$ or $\mathrm{T}$ ) is not found in most mammalian cells but has been detected in pluripotent cells $(9,10)$, some human tissues $(11)$, and is enriched in postnatal neurons (12-14). The $\mathrm{mCH}$ mark increases in neurons predominantly after birth and concurrent with the period of peak synaptogenesis throughout the first 25 years of life in humans (or first 4 weeks in mice). The resulting $\mathrm{mCH}$ pattern is largely conserved between mice and humans, where it makes up a high percentage of all DNA methylation in neurons $(12,13,15)$. Although the timing and specification of $\mathrm{mCH}$ suggest it serves a critical function in maturing neurons, the molecular mechanism and functional consequences for loss of the $\mathrm{mCH}$ mark remain understudied.

In mammals, DNA methylation is catalyzed by de novo DNA methyltransferases Dnmt3a and Dnmt3b, and maintained by Dnmt1 in a CpG context (16). Recent studies have shown that Dnmt3a is the sole "writer" of $\mathrm{mCH}$ in postnatal neurons $(13,17-19)$, where it is preferentially found in the CAC nucleotide context (12). Mutations in DNMT3A have recently been associated with disorders of neurodevelopment (20-22) suggesting that the mechanism by which Dnmt3a dependent methylation is written and read by other protein factors to regulate gene expression is critical for brain maturation. Loss of function of the only known "reader" of $\mathrm{mCH}$ in the mammalian brain, Methyl-CpG-binding protein 2 (MeCP2) $(17,18,23)$, has long been associated with Rett syndrome (RTT) (24). RTT is an X-linked, postnatal neurological disorder; affected children are apparently healthy for the first 6-18 months of life, then lose their acquired milestones and develop a range of dysfunctions of the central and autonomic nervous systems $(25,26)$. Mouse models of $M E C P 2$ mutations in female mice faithfully recapitulate 
patient symptoms, the severity of which, in humans and mice, is determined by the specific mutation and the pattern of $\mathrm{X}$-inactivation $(25,27,28)$. Numerous conditional knockout mice have revealed the function for MeCP2 in different cell populations in the brain as well as the etiology of RTT symptoms (29-41). Given the apparent need of every neural cell type for $\mathrm{MeCP} 2$, it is not surprising that $M E C P 2$ mutations have been linked to other neuropsychiatric conditions beyond RTT $(26,28)$. Yet re-expression of MeCP2 in the CNS (42) rescues even the severe neurological symptoms and the prematurely lethal phenotype of constitutive null male mice $(29,41)$. RTT is thus driven by the loss of MeCP2 function in the nervous system, which continues to be essential into adulthood $(43,44)$, but the underlying architecture is sufficiently intact to support functional rescue.

Despite decades of research, the precise mechanism by which MeCP2 drives RTT phenotypes remains enigmatic. The recent finding that $\mathrm{MeCP} 2$ binds to $\mathrm{mCH}$ at disease-associated genes, and that $\mathrm{mCH}$ deposition occurs predominantly after birth and in conjunction with neuronal maturation, has led to the hypothesis that failure of mutant $\mathrm{MeCP} 2$ to bind to $\mathrm{mCH}$ could account for the postnatal onset of RTT symptoms (23). Whether loss of $\mathrm{MeCP} 2$ binding to $\mathrm{mCH}$ is sufficient to cause $\mathrm{RTT}$ has not been explored.

Here we set out to answer if $\mathrm{MeCP} 2$ is the only reader that interprets the unique methylation pattern set by Dnmt3a to direct gene expression in the maturing brain. If $\mathrm{MeCP} 2$ is the sole reader of these methylation marks, then loss of function of the writer should produce the same phenotype as loss of the reader at the behavioral and physiological level, as well as the same changes in gene expression at the molecular level. Such comparisons must be done in a cell-specific manner, since both mCH methylation (45) and the effects of MeCP2 loss are highly cell-specific (29-41). No one has performed a cell-type specific head-to-head comparison of knockout models at the behavioral, physiological and molecular level, which is necessary to define the functional relationship between Dnmt3a and MeCP2 in the nervous system. In this study, therefore, we systematically compared the effects of cell-specific knockout for Dnmt $3 a$ and Mecp2 in mice of the same genetic background at the behavioral, physiological, and molecular level. We chose GABAergic inhibitory neurons for this comparison because knockout of Mecp2 in this cell type recapitulates most of the RTT phenotype, including the delayed symptom onset (33), and loss of Dnmt3a and the methylation pattern it sets in inhibitory neurons has not been previously studied. Intriguingly, our findings indicate that while $\mathrm{mCH}$ has significant contribution to RTT, MeCP2 is responsible for enacting only a subset of Dnmt3a dependent gene regulation suggesting that there are other functional factors in this novel epigenetic pathway yet to be discovered that may impact neuropsychiatric phenotypes. 


\section{Results}

\section{Loss of Dnmt3a or MeCP2 in inhibitory neurons produces overlapping but not identical behavioral} phenotypes

To compare the effects of loss of the $\mathrm{mCH}$ "writer" and "reader", we deleted Dnmt3a or Mecp2 utilizing floxed alleles for each gene in combination with a mouse line that drives Cre expression in GABAergic inhibitory neurons (Viaat-Cre) $(29,33,46)$. We chose the Viaat promoter to drive Cre expression because it has been shown to turn on in the central nervous system around embryonic day 10 (47), before the earliest mCH marks have been detected in the brain ( embryonic day 12.5 in the hindbrain) (15). We previously characterized mice with conditional knockout (cKO) of Mecp2 in the same neurons on an F1 hybrid background (33), but to directly compare loss of the writer and reader we re-derived the Mecp $2 \mathrm{cKO}$ on the C57BL/6J background. Conditional knockout mice showed loss of either Dnmt3a or MeCP2, respectively (Supplemental Figure 1A- B). We then tested both lines of mice for the same behavioral abnormalities previously reported (33).

Both cKO mice were born healthy but started to display symptoms around the time of weaning. Table 1 summarizes the phenotypes, showing that there is considerable overlap in the phenotypes but also specific features that are present in only one of the models (see Supplemental Table 1 for statistics). Both cKO mice first developed hind limb spasticity (Figure 1A), and by six weeks both Dnmt $3 a$ cKO and Mecp 2 cKO mice displayed obsessive grooming (Figure 1B), forepaw apraxia (Figure 1C), muscle weakness (Figure 1D), and motor deficits (Figure 1E, Supplemental Figure 2A). We found hippocampal-dependent, but not amygdala-dependent, learning and memory deficits (Figure 1F, Supplemental Figure 2C). Both mouse lines showed similar trends in anxiety-like behaviors (Supplemental Figure 2D-F), with Mecp2 cKO achieving significance in one test (Supplemental Figure 2F). Starting at 7 to 8 weeks of age, the obsessive grooming led to skin lesions (Figure 1G); this self-injury was previously observed in Mecp 2 cKO mice on an F1 hybrid background (33) but was exacerbated on the C57BL/6J background, creating a need for humane euthanasia (see Methods). This shortened the period we were able to perform behavioral testing on both cKO mouse models. Both cKO mouse models still responded to pain stimuli (Supplemental Figure 2G-H), albeit to a lesser degree than controls. Rotarod and social interaction deficits that manifest in Mecp $2 \mathrm{cKO}$ mice later in life on a F1 hybrid background did not develop within the foreshortened observation period (Supplemental Figure 2I-J).

To compare cKO mouse models at the physiological level we measured miniature inhibitory postsynaptic currents (mIPSCs) in the dorsal striatum of Dnmt $3 a \mathrm{cKO}, M e c p 2 \mathrm{cKO}$, and control mice. 
We observed decreased amplitude, as well as similar changes in frequency and charge (Figure 1H-I, Supplemental Figure 2K-L). Differences were not apparent in measurements of rise or decay time (Supplemental Figure 2M-N).

Despite these similarities, there were also clear differences between the cKO mice. Dnmt $3 a \mathrm{cKO}$ mice were smaller than control mice starting at weaning age and throughout adulthood (Figure 1J). Forepaw stereotypies were evident in Dnmt $3 a$ cKO mice but not the Mecp $2 \mathrm{cKO}$ mice on the C57BL/6J background (Supplemental Movie 1). Loss of Dnmt3a in inhibitory neurons led to an increased acoustic startle response (Figure 1K), with loss of MeCP2 in the same cell type showing the opposite trend, similar to a previous MeCP2 study (33). Only the Mecp 2 cKO mice developed motor incoordination (Figure 1L) and showed a trend for increased sensorimotor gating (Supplemental Figure 20). Dnmt3a cKO mice also showed deficits in conditioned fear training (Supplemental Figure 2B). Finally, the Dnmt3a cKO mice showed much more severe self-injury, requiring humane euthanasia 2.5-week earlier than Mecp2 cKO mice (Figure 1M).

\section{MeCP2 is a partial reader of Dnmt3a dependent methylation in striatal inhibitory neurons}

Our behavioral data suggest that Dnmt3a and MeCP2 are functionally related, but it is still unclear what proportion of genes marked by Dnmt3a dependent methylation are regulated via MeCP2. To determine this, we tested our model that assumes MeCP2 is the only functional reader for these marks by sequencing the DNA methylome using a modified snmC-seq method adapted for bulk DNA samples (see Methods). We also performed RNA-seq on sorted GABAergic inhibitory neuronal nuclei from the striatum of Dnmt3a cKO, Mecp $2 \mathrm{cKO}$, and wild-type mice via the INTACT method (45) (Figure 2A). The striatum is ideal because $\mathrm{mCH}$ patterns are highly cell-specific and the vast majority of neurons $(95 \%)$ in this region are inhibitory medium spiny neurons $(48,49)$. We found that methylation was stable in the absence of MeCP2 (Figure 2B, Supplemental Figure 3), but the Dnmt3a conditional knockout lost $\sim 90 \%$ of $\mathrm{mCH}$ (Figure 2C). We also noted a $\sim 10 \%$ loss of $\mathrm{mCG}$ in Dnmt $3 a$ cKO neurons (Figure 2D) consistent with partial $\mathrm{mCG}$ demethylation in the prenatal period followed by re-methylation later in development $(15,19)$. Dnmt3a is thus required to re-methylate $\mathrm{mCG}$ sites in the postnatal period. To determine if $\mathrm{mCH}$ and $\mathrm{mCG}$ marks written by Dnmt3a are coincident at genomic loci or independent of one another, we plotted the percentage of $\mathrm{mCH}$ versus $\mathrm{mCG}$ per gene in wild-type mice, as well as restricting the analysis to Dnmt3a dependent methylation (the change in methylation observed in the Dnmt $3 a$ cKO is defined as "Dnmt3a dependent"). While $\mathrm{mCH}$ and $\mathrm{mCG}$ in wild-type mice showed poor genome-wide correlation (Figure 2E), Dnmt3a dependent $\mathrm{mCH}$ and $\mathrm{mCG}$ showed significant correlation suggesting that the writing of $\mathrm{mCH}$ and $\mathrm{mCG}$ are coupled (Figure 2F). 
Comparing gene expression by RNA-Seq for both knockout models, we found hundreds of differentially expressed genes (DEGs), either up- or down-regulated (Figure 3A, Supplemental Table 2). Although a large portion of DEGs in our Mecp $2 \mathrm{cKO}$ model were significantly altered in Dnmt $3 a \mathrm{cKO}$ mice ( 40\%) indicating a dependence on Dnmt3a and an important contribution to RTT, we were surprised to find that only a small percentage of DEGs in our Dnmt3a cKO model were significantly altered in Mecp 2 cKO mice (i.e. are "MeCP2 dependent", 12\%) (Figure 3B). The amount of overlap was consistent at different p-value thresholds, and whether we considered only the DEGs that were upregulated, down-regulated, or of certain length (Supplemental Figure 4A-C, Supplemental Table 2). Plotting the $\log 2$ fold-change in gene expression for each model against one another (Figure 3C), we found that DEGs common to both $\mathrm{cKO}$ models changed in the same direction and to a similar degree, consistent with an equal dependence on Dnmt3a and MeCP2. In all, our data show that MeCP2 is a restricted reader for Dnmt3a dependent methylation providing a platform for discovering novel functional factors in this pathway, as well as highlight a subset of genes regulated by $\mathrm{MeCP} 2$ that appear independent of Dnmt3a and the methylation it sets.

\section{Integrative gene expression and methylation analysis shows $\mathrm{mCH}$ and $\mathrm{mCG}$ loss contribute to Dnmt3a cKO DEGs, and reveals a strong $\mathrm{mCH}$ contribution to RTT}

Plotting gene body $\mathrm{mCH}$ in wild-type mice for each category of differentially expressed genes, we find that, overall, DEGs have greater gene body $\mathrm{mCH}$ than genes that are unchanged, with up-regulated genes showing the biggest difference (Figure 4A). The same analysis showed that mCG levels are also higher on DEGs than non-DEGs for the majority of DEGs categories (Figure 4B), suggesting total methylation may also influence the final transcriptional outcome (50). Gene body methylation levels for all genotypes and statistics for comparisons can be found in Supplemental Figure 5. To elucidate the relative contribution of $\mathrm{mCH}$ or $\mathrm{mCG}$ written by Dnmt3a to gene expression changes in our cKO models, we employed a similar method to previous publications (19) and examined running average plots for the $\log 2$ fold-change in gene expression for each $\mathrm{cKO}$ model versus the percent change in Dnmt3a dependent methylation. These data were then fit with a univariate linear model to determine the percentage variance in $\log 2$ fold change explained by either $\mathrm{mCH}$ or $\mathrm{mCG}\left(\mathrm{R}^{2}\right.$, see Methods). For genes significantly misregulated only in the Dnmt $3 a$ cKO model we found a correlation with both Dnmt3a dependent $\mathrm{mCH}$ and $\mathrm{mCG}$ (Figure 4C), consistent with these marks being part of the same epigenetic program. These trends were statistically robust as when the same analysis was done 1000 times using random sets of nonDEG genes, the $\mathrm{R}^{2}$ values for our selected set of DEGs were significantly higher (Figure 4G, see Methods). The same trends hold when plotting the fold change in gene expression in the Dnmt $3 a$ cKO 
for genes that are commonly misregulated in both cKO models (Figure 4D,H). When we plot these commonly misregulated genes against the fold change in gene expression in the $M e C P 2 \mathrm{cKO}$, we find a strong dependence on the change in gene expression to the change in $\mathrm{mCH}$ but not $\mathrm{mCG}$ (Figure 4E,I). As expected significant trends were not observed for Dnmt3a dependent methylation when plotting DEGs that were only significantly misregulated in the $M e C P 2 \mathrm{cKO}$ mice (Figure $4 \mathbf{F}, \mathbf{J})$. This integrative analysis demonstrates that loss of Dnmt3a dependent $\mathrm{mCH}$ and $\mathrm{mCG}$ significantly contributes to gene expression changes seen in the Dnmt3a cKO. Importantly we find that $\mathrm{mCH}$, but not Dnmt3a dependent $\mathrm{mCG}$, does in fact play a central role in mediating RTT pathogenesis.

\section{Discussion}

The discovery of $\mathrm{mCH}$ in postnatal neurons has shifted the view of how epigenetic gene regulation occurs in the brain. Beyond the obvious difference of unique context and cell-type restriction, the postnatal dynamics of this epigenetic program immediately suggest an important role for $\mathrm{mCH}$ in directing gene expression to ensure fully mature and functional neurons. Here we find that conditional knockout of the $\mathrm{mCH}$ writer, Dnmt $3 a$, in GABAergic inhibitory neurons leads to genome-wide loss of $\mathrm{mCH}$ and a small subset of $\mathrm{mCG}$ sites, causing hundreds of gene expression changes and impairs neurophysiology and behavior with some deficits mirrored in a matched deletion of Mecp2. We were surprised to find only a modest contribution of MeCP2 to Dnmt3a/methylation dependent DEGs in our RNA-seq analysis. From this and our integrated gene expression and methylation analyses we distill two major conclusions. First, binding of $\mathrm{MeCP} 2$ to postnatal $\mathrm{mCH}$ contributes significantly to postnatal RTT symptoms, but there still appear to be other genomic targets recognized by $\mathrm{MeCP} 2$ or other functions whose loss contributes to the disease. Second, though MeCP2 "reads" a subset of Dnmt3a/methylation regulated genes, there appears to be a much broader gene regulatory program set up by the placement of global $\mathrm{mCH}$ and some $\mathrm{mCG}$ via Dnmt3a. These findings highlight the need to compare gene function at multiple biological scales, the molecular level in particular, when drawing conclusions about the functional relationship between proteins.

Uncovering the relationship between Dnmt3a and $\mathrm{MeCP} 2$ in the nervous system is challenging for a several reasons. First, while the phenotypes observed in whole-body knockout of Mecp 2 are recapitulated in the brain-specific knockout $(29,41)$, the phenotypes of whole-body (51) and brain-specific (52) knockout of Dnmt3a diverge, highlighting the essential role of Dnmt3a in peripheral tissues. In addition, while prior studies showed that early deletion of Dnmt3a in the brain drives neurological symptoms $(52,53)$, deletion of Dnmt3a using Cre-drivers that turn on postnatally have been demonstrated to produce minor (54) to no neurological symptoms (55). Therefore, it is likely that the underlying methylation 
pattern remains largely unaffected if Dnmt3a is deleted later in development, precluding the evolution of deficits. This is in contrast to $\mathrm{MeCP} 2$, where phenotypes are observed regardless of when the gene is deleted $(43,44)$. Our study deliberately eliminated these variations and shows that Dnmt3a and MeCP2 have overlapping but distinct roles to produce functionally normal neurons and behaviors. These data highlight the importance of extensive direct comparison between knockout models in a selected cell type, on the same genetic background, and to consider the developmental contribution for each gene being compared.

While DNA methylation remains stable in the absence of MeCP2, we find that loss of Dnmt3a in inhibitory neurons before birth leads to global loss of $\mathrm{mCH}$, with a minor drop in $\mathrm{mCG}(\sim 10 \%)$, consistent with previous studies $(13,15,19)$. The loss of $\mathrm{mCG}$ is likely due to de-methylation in the embryonic brain $(13,15)$ that cannot be re-methylated in the absence of Dnmt3a. At the RNA level, we show that loss of either Dnmt3a or MeCP2 leads to misregulation of hundreds of genes that normally have higher methylation ( $\mathrm{mCH}$ in particular) relative to genes that are unchanged. We find expression of these genes changes in both the up and down direction in a manner that is independent of gene length. Importantly, the vast majority of the genes misregulated in both cKO models change to a similar degree and in the same direction, consistent with equal dependence of these genes on Dnmt3a and MeCP2 for proper regulation. While our data cannot rule out the possibility that secondary changes to gene expression may be occurring, the percentage of overlapping DEGs between cKO models is robust to pvalue cutoff, direction of change or gene length. Integrating our genomic datasets, we find a significant contribution of $\mathrm{mCH}$ and $\mathrm{mCG}$ to the fold change in gene expression in the Dnmt $3 a \mathrm{cKO}$ consistent with these marks functioning together to regulate gene expression during neuronal maturation. Intriguingly, we see a significant contribution of $\mathrm{mCH}$, but not $\mathrm{mCG}$ to the misregulation of a subset of genes in the $\mathrm{MeCP} 2 \mathrm{cKO}$. This together with overlapping behavioral and physiological data suggests that binding of $\mathrm{MeCP} 2$ to $\mathrm{mCH}$ is critical for the postnatal evolution of RTT symptoms.

Our molecular data suggest that $\mathrm{MeCP} 2$ is likely one of a number of functional factors interpreting Dnmt3a dependent methylation. Though the overlap in gene expression changes between models has not been quantified until here, re-analysis of single-nuclear RNA-seq datasets from cortical inhibitory neurons (19) are consistent with our conclusion (Supplemental Figure 6). However, our data show a stronger dependence of MeCP2 DEGs on Dnmt3a function. With these data in hand we propose that the current model for Dnmt3a dependent gene regulation (19) be updated to incorporate our insights that $\mathrm{MeCP} 2$ is a restricted reader for Dnmt3a dependent gene regulation, as well as that postnatal mCG plays a role in the epigenetic program driven by Dnmt3a during neuron maturation.

There is a defined set of proteins in the mammalian genome that possess a methyl binding domain 
(MBD) and have been shown to bind $\mathrm{mCH}$ in vitro (56). These data highlight these proteins as primary candidates, though further studies are necessary to determine whether the other MBD-containing proteins read $\mathrm{mCH}$ in the brain, in vivo. However, there are other proteins involved in transcriptional regulation that do not possess a classic MBD and are sensitive to the methylation status of DNA, with some validated in vivo (57-61). For example, the DNA binding of many transcription factors is both positively and negatively affected by DNA methylation $(58,59)$, a phenomena that is not exclusive to mammals (62). Further, the DNA methylation and histone modification machinery are intimately linked (61). This link has been specifically shown in the differentiation of neural precursor cells, where methylation written by Dnmt3a antagonizes polycomb complexes to modulate gene expression (60). Given these findings, it is possible that similar mechanisms involving non-canonical methylation readers could be at play in Dnmt3a dependent gene regulation. Therefore, it will be important to undertake unbiased approaches to elucidate the full set of protein factors that drive gene regulation in this novel epigenetic pathway. All in all, our discovery that $\mathrm{MeCP} 2$ reads only some Dnmt3a dependent methylation marks lays the groundwork to uncover novel factors responsible for postnatal gene regulation that may be critical in setting up a mature, healthy mammalian brain.

\section{Materials and Methods}

\section{Animal husbandry and handling}

Baylor College of Medicine Institutional Animal Care and Use Committee (IACUC, Protocol AN1013) approved all mouse care and manipulation. Mice were housed in an AAALAS-certified Level 3 facility on a $14 \mathrm{hr}$ light-10hr dark cycle. To obtain Dnmt $3 a \mathrm{cKO}$ and control mice for behavior and electrophysiology, Dnmt3 $a^{\text {flox/flox }}$ mice(46) (C57BL6 background) were bred to Viaat-Cre ${ }^{+/+}$mice(33) (C57BL/6J background) and Dnmt3a flox/flox mice were bred to wild-type mice (C57BL/6J background) to get F1 Dnmt $3 a^{\text {flox } /+}$;Viaat-Cre ${ }^{+/-}$females and Dnmt $3 a^{\text {flox/+ }}$ males, respectively. F1 Dnmt $3 a^{\text {flox/+/}}$; Viaat-Cre ${ }^{+/-}$ females were mated with $D n m t 3 a^{\text {flox/+ }}$ or Dnmt $3 a^{\text {flox/flox }}$ males to obtain F2 mice (males and females) of

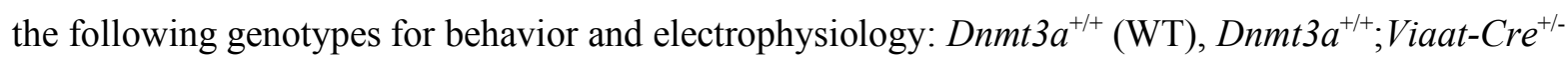

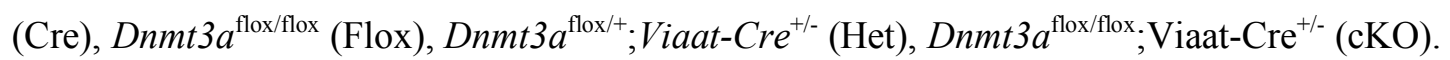
Importantly, female mice carrying the Cre allele at F1 were used in F2 mating as we discovered that

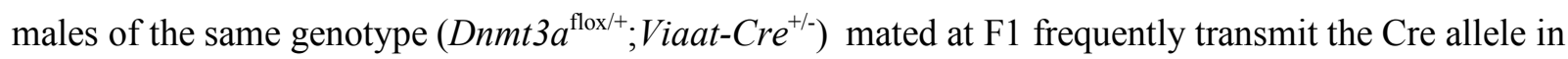
the germline resulting in Dnmt $3 a$ null mice. To obtain Mecp $2 \mathrm{cKO}$ and control mice behavior and electrophysiology, Mecp $2^{\text {flox/flox }}$ females(29) (C57BL/6J background) were mated to Viaat-Cre ${ }^{+/-}$males (C57BL/6J background) to get F1 male mice of the following genotypes: $\operatorname{Mecp}^{+/ y}$ (WT), Mecp2 ${ }^{+/ y}$;Viaat- 
$\mathrm{Cre}^{+/-}(\mathrm{Cre}), \mathrm{Mecp}^{\mathrm{flox} / \mathrm{y}}$ (Flox), Mecp $2^{\text {flox/y}} ;$ Vial $_{\text {-Cre }}{ }^{+/-}(\mathrm{cKO})$. Weekly weights and health scores were taken according to previously described disease score scale(63). For electrophysiological recordings control mice (WT and Cre) were shared for analysis and taken from both breeding schemes.

To obtain Dnmt3a cKO, Mecp 2 cKO and WT mice suitable for INTACT biochemistry experiments the breeding was as follows. Dnmt $3 a^{\text {flox/flox }}$ mice were bred to R26-CAG-LSL-Sun1-sfGFP-Myc ${ }^{+/+}$ mice(45) (C57BL/6J background) until both alleles were homozygosed to get Dnmt $3 a^{\text {flox/flox }} ; R 26-C A G$ LSL-Sun1-sfGFP-Myc $c^{+/+}$mice. Dnmt3 $a^{\text {flox/flox } ; R 26-C A G-L S L-S u n 1-s f G F P-M y c ~}{ }^{+/+}$males were mated with

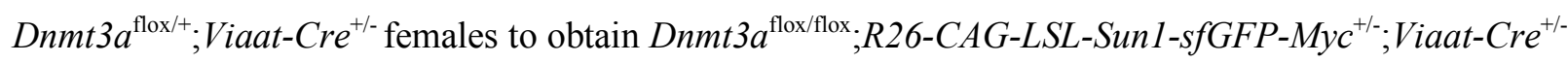
male mice used for biochemistry of striatal inhibitory neurons that lack Dnmt3a. Mecp $2^{\text {flox/flox }}$ females were mated to R26-CAG-LSL-Sun1-sfGFP-Myc ${ }^{+/+}$mice males until both alleles were homozygosed to obtain Mecp $2^{\text {flox/flox }} ; R 26-C A G-L S L-S u n 1-s f G F P-M y c^{+/+}$female mice. Mecp $2^{\text {flox/flox }} ; R 26-C A G-L S L-S u n 1-$ $s f G F P-M y c^{+/+}$female mice were mated to Viaat-Cre ${ }^{+/+}$males to get Mecp $2^{\text {flox/y }} ; R 26-C A G-L S L-S u n 1-$ $s f G F P-M y c^{+/-} ;$Viaat-Cre ${ }^{+/-}$male mice used for biochemistry of striatal inhibitory neurons that lack $\mathrm{MeCP} 2$. To obtain male mice used for biochemistry of wild-type striatal inhibitory neurons, $R 26-C A G$ LSL-Sun1-sfGFP-Myc $\mathrm{C}^{+/+}$mice were bred to Viaat-Cre ${ }^{+/+}$mice to get R26-CAG-LSL-Sun1-sfGFP-Myc $c^{+/-}$ ;Viaat-Cre ${ }^{+/-}$male mice. For all cohorts of mice, mixed genotypes were housed separated by sex up to 6 mice per cage until 6-weeks of age and reduced to no more than 5 per cage after 6-weeks.

Before experimental cohorts were subject to investigation we noted Dnmt $3 a \mathrm{cKO}$ and Mecp $2 \mathrm{cKO}$ mice had a self-injury phenotype leading to skin lesions. Therefore, the institutional veterinarian was consulted to define humane euthanasia endpoint criteria for further experiments. Mice with lesions could be treated with antibiotic cream, and mice were euthanized when lesions extended below the skin layer. Survival age was taken as the age in which a mouse died of natural causes or when a mouse was euthanized due to skin lesions according to the institutional veterinarian guidelines set beforehand. Investigators were blind to genotypes of experimental mice until behavioral tests were finalized.

\section{Mouse Behavioral tests}

Dnmt $3 a \mathrm{cKO}, M e c p 2 \mathrm{cKO}$, and control mice were assigned individual ID numbers and the experimenters were blinded to genotype for the duration of behavioral testing. Experimental mice were divided into two cohorts for testing. Cohort 1 mice were subjected to the following tests, in order, at 6 weeks of age: open field, grooming, hotplate and tail flick, grip strength, parallel rod footslip, and prepulse inhibition/acoustic startle. The same mice were tested for conditioned fear at 8 weeks. Cohort 2 mice were subjected to the following tests, in order, at 6 weeks of age: elevated pus maze, light/dark box, rotarod, and partition/nesting. All behavioral assays were conducted during the light cycle, generally in 
the afternoon. All tests were conducted in light conditions.

All behavior data was analyzed using GraphPad Prism version 6 (GraphPad Software, La Jolla California USA, www.graphpad.com). Results were considered to be significant at $\mathrm{p}<0.05$ and statistical significance reported in figures using a star notation to represent the lowest significance reached in the comparison $\left(*_{p}<0.05, * * p<0.01, * * * p<0.001, * * * *<0.0001\right)$. After behavioral analysis of the Dnmt3a cohort separated by both sex and genotype was completed, we determined that there was no statistical difference between males and females with the exception of body weight. Therefore, data for male and female mice were merged with the exception of body weight measures in the final analysis reported here. Statistical analysis for only males in the Dnmt3a cohort can also be found in Supplemental Table 1.

\section{Grooming}

Mice were habituated in the test room for 30 minutes. Each mouse was individually placed in a clean housing cage without food, food grate, or water for 10 minutes. They were then videotaped for an additional 10 minutes. After recording, the mice were returned to their home cage. Videos were scored for grooming time by an investigator blind to the genotype of the test mouse. Data is shown as mean \pm standard error of mean and was analyzed by one-way ANOVA with Tukey's post hoc analysis.

\section{Grip Strength}

Mice were habituated in the test room for 30 minutes. Each mouse was allowed to grab the bar of a digital grip strength meter (Columbus Instruments, Columbus, $\mathrm{OH}$ ) with both forepaws while being held by the tail and then pulled horizontally away from the meter with a constant slow force until the forepaws released. The grip (in $\mathrm{kg}$ of force) was recorded and the procedure repeated for a total of three pulls. Data shown is the average of the three pulls presented as mean \pm standard error of mean. Grip strength was analyzed by one-way ANOVA with Tukey's post hoc analysis.

\section{Open Field}

Mice were habituated for 30 minutes in the test room lit at 200 lux with white noise playing at $60 \mathrm{~dB}$. Each mouse was placed singly in the open field apparatus (OmniTech Electronics, Columbus, $\mathrm{OH}$ ) and allowed to move freely for 30 minutes. Locomotion parameters and zones were recorded using Fusion activity monitoring software. Data is shown as mean \pm standard error of mean and was analyzed by oneway ANOVA with Tukey's post hoc analysis.

\section{Fear Conditioning}


Mice were habituated for 30 minutes outside the test room. Mice were placed singly into the conditioned fear apparatus (Coulbourn Instruments, Holliston, MA) that consisted of a lighted box with a floor made of parallel metal bars. On the training day, mice were placed in the chamber and subjected to two rounds of training, each of which consisted of 180 seconds of silence followed by a 30 second-long $80-85 \mathrm{~dB}$ tone and 2 seconds of a $0.72 \mathrm{~mA}$ shock. 24 hours after training, the mice were returned to the box where they received the shock and freezing behavior recorded for six minutes. One hour later, the grated floor of the test chamber was covered, the shape changed with plastic panels, and vanilla scent added to the chamber. Mice were returned to the apparatus and subjected to a cue test consisting of 180 seconds of silence followed by 180 seconds of the original $80-85 \mathrm{~dB}$ tone. Freezing behavior for all tests was scored using Freeze Frame 3 software (Actimetrics) with a threshold of 5.0. Data is shown as mean \pm standard error of mean. Cue tests were analyzed by two-way ANOVA with Bonferroni's post hoc analysis.

\section{Hot Plate and Tail Flick}

Mice were habituated for 30 minutes in the test room prior to testing. Each mouse was placed individually on a $55^{\circ} \mathrm{C}$ hot plate (Stoelting Co., Wood Dale, IL) and observed for jumping, vocalization, hind paw lifting, or licking of the hind paws. At the first incidence of any of these behaviors the mouse was removed from the hot plate and the elapsed time noted. 30 minutes after the hot plate test, the mouse was placed on the tail flick apparatus (Stoelting Co., Wood Dale, IL) and restrained with a paper towel laid over the mouse and held down gently by the experimenter's hand. The tail was laid in the groove above the lamp but was not restrained. The lamp was then turned on at 5-6eWatts; this also started the timer, which stopped automatically when the mouse moved its tail away from the lamp. The mouse was then returned to its home cage. Data was analyzed by one-way ANOVA with Tukey's post hoc analysis.

\section{Elevated Plus Maze}

Mice were habituated for 30 minutes in the test room lit at 200 lux with white noise playing at $60 \mathrm{~dB}$. The elevated plus maze is a plus sign-shaped maze with two opposite arms enclosed by walls and two opposite arms open without walls. The entire maze is elevated above the floor. Mice were placed singly at the intersection of the four arms and allowed to move freely for 10 minutes. Activity was recorded by a suspended digital camera and recorded by the ANY-maze software (Stoelting Co., Wood Dale, IL). Data is shown as mean \pm standard error of mean. Time and distance in the open arm were each analyzed by one-way ANOVA with Tukey’s post hoc analysis.

\section{Light/Dark Box}


Mice were habituated for 30 minutes in the test room lit at 200 lux with white noise playing at $60 \mathrm{~dB}$. Mice were placed singly in the light side of the light dark apparatus (Omnitech Electronics, Columbus, $\mathrm{OH})$ and allowed to move freely for 10 minutes. Locomotion parameters and zones were recorded using Fusion activity monitoring software. Data is shown as mean \pm standard error of mean. Time in Light was analyzed by one-way ANOVA with Tukey's post hoc analysis.

\section{Parallel Rod Footslip}

Mice were habituated in the test room for 30 minutes. Each mouse was placed in a footslip chamber consisting of a plexiglass box with a floor of parallel-positioned rods and allowed to move freely for 10 min. Movement was recorded by a suspended digital camera, while footslips were recorded using ANYmaze software (Stoelting Co.). At the completion of the test, mice were removed to their original home cage. Total footslips were normalized to the distance traveled for data analysis. Data is shown as mean \pm standard error of mean and analyzed by one-way ANOVA with Tukey's post hoc analysis.

\section{Acoustic Startle Response and Prepulse Inhibition}

Mice were habituated for 30 minutes outside the test room. Each mouse was placed singly in SR-LAB PPI apparatus (San Diego Instruments, San Diego, CA), which consisted of a Plexiglass cylindrical tube in a sound-insulated lighted box. Once restrained in the tube, the test mouse was allowed to habituate for 5 minutes with $70 \mathrm{~dB}$ white noise playing. The mouse was presented with eight types of stimulus, each presented six times in pseudo-random order with a 10-20 ms inter-trial period: no sound, a $40 \mathrm{~ms} 120 \mathrm{db}$ startle burst, three $20 \mathrm{~ms}$ prepulse sounds of 74,78 , and $82 \mathrm{~dB}$ each presented alone, and a combination of each of the three prepulse intensities presented $100 \mathrm{~ms}$ before the $120 \mathrm{~dB}$ startle burst. After the test, mice were returned to their home cage. The acoustic startle response was recorded every $1 \mathrm{~ms}$ during the $65 \mathrm{~ms}$ period following the onset of the startle stimulus and was calculated as the average response to the $120 \mathrm{db}$ startle burst normalized to body weight. Percent prepulse inhibition was calculated using the following formula: (1-(averaged startle response to prepulse before startle stimulus/averaged response to startle stimulus)) x 100. Data are shown as mean \pm standard error of mean. Percent prepulse inhibition was analyzed by two-way ANOVA with Bonferroni's post hoc analysis, and acoustic startle response was analyzed by one-way ANOVA with Tukey's post hoc analysis.

\section{Rotarod}

Mice were placed on the rotating cylinder of an accelerating rotarod apparatus (Ugo Basile, Varese, Italy) and allowed to move freely as the rotation increased from $5 \mathrm{rpm}$ to $40 \mathrm{rpm}$ over a five-minute period. 
Latency to fall was recorded when the mouse fell from the rod or when the mouse had ridden the rotating rod for two revolutions without regaining control. This procedure was repeated for a total of four trials for two days. Data is shown as mean \pm standard error of mean. Latency to fall was analyzed by two-way ANOVA with Bonferroni’s post hoc analysis.

\section{Partition test and nesting analysis}

Mice were single-housed for 48 hours on one side of a standard housing cage. The cage was divided across its width by a divider with holes small enough to allow scent but no physical interaction. The test mouse was provided with a KimWipe folded in fourths as nesting material. At $24 \mathrm{hr}$ and $48 \mathrm{hr}$ of singlehousing, the KimWipe was assessed for nesting score, as described previously(33). At least 16 hours before the partition test, a novel age- and gender-matched partner mouse of a different strain was placed on the opposite side of the partition. On the day of the test, the cage was placed on a well-lit flat surface. All nesting material, food pellets, and water bottles were removed from both sides of the cage, and the test mice were observed for 5 minutes while interaction time with the now-familiar partner mouse was recorded. Interactions involved the test mouse smelling, chewing, or actively exploring the partition. At the end of the first test (Familiar 1), a novel mouse of the same age, gender, and strain replaced the familiar partner mouse, and test mouse interactions were recorded for five minutes (Novel). The novel mouse was then removed and the familiar partner mouse returned to the cage, followed by observation for another 5 minutes (Familiar 2). At the completion of the partition test, test mice were returned to their original home cage. Data is shown as mean \pm standard error of mean. Interaction times were analyzed by two-way ANOVA with Bonferroni's post hoc analysis, and nesting scores were analyzed by one-way ANOVA with Tukey's post hoc analysis.

\section{Western Blots}

2- week old Dnmt3a ${ }^{\text {flox/flox }} ; R 26-C A G-L S L-S u n 1-s f G F P-M y c^{+/} ;$Viaat-Cre ${ }^{+/-}$and R26-CAG-LSL-Sun1-

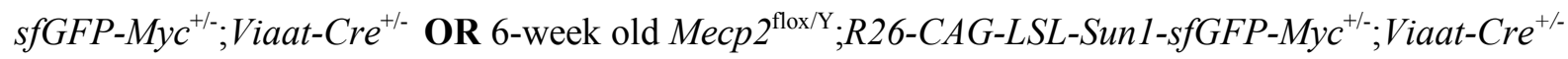
and R26-CAG-LSL-Sun1-sfGFP-Myc ${ }^{+/-}$;iaat-Cre ${ }^{+/-}$male were anaesthetize with isoflurane, whole brains dissected, split in half, frozen in liquid nitrogen and stored at $-80^{\circ} \mathrm{C}$ till processing. Half-brains were thawed in $2 \mathrm{~mL}$ lysis buffer (20mM HEPES pH 7.4, 200mM NaCl, 100mM Na $3 \mathrm{PO}_{4}, 10 \%$ Triton X-100, 1X protease inhibitor (Sigma Cat\#5056489001), 1:2000 Universal Nuclease (Sigma Cat\# 88701), dounced 50X with tight pestle and incubated on ice for 20min. Lysates were spun down 2x 20 minutes at $13,200 \mathrm{rpm}$ at $4^{\circ} \mathrm{C}$ saving the supernatant each time. $20 \mu \mathrm{g}$ of protein was loaded onto a NuPAGE $4-12 \%$ Bis-Tris gradient gel and run in MES Running Buffer (Thermo Fisher Cat\#NP0321BOX and NP000202, 
respectively). Protein bands were transferred to a nitrocellulose membrane in Tris-Glycine buffer plus $10 \%$ methanol at $400 \mathrm{~mA}$ for $1 \mathrm{hr}$ at $4^{\circ} \mathrm{C}$. Membrane was blocked with $5 \%$ milk in tris buffered saline with $2 \%$ Tween-20 (TBST) for $1 \mathrm{hr}$ at room temperature (RT), cut and appropriate segments stained with primary antibodies overnight at $4^{\circ} \mathrm{C}$. Membranes were washed in 1X TBST 3x for 5 minutes at RT and stained with secondary antibodies at $4^{\circ} \mathrm{C}$ for $1 \mathrm{hr}$, followed by repeated washes in $1 \mathrm{XTBST}$. ECL detection kit (Fisher 45010090) was used to detect HRP. Antibodies used were: 1:1000 anti-Dnmt3a (Santa Cruz 20703), 1:1000 anti-MeCP2 (in house N-terminal antibody), 1:20,000 anti-histone H3 (Abcam 1791) for primary antibodies, and 1:10,000 goat anti-rabbit-HRP (BioRad 170-5046) for the secondary antibody. Data is shown as mean \pm standard error of mean and subject to unpaired $t$ test with Welch's correction for statistical analysis.

\section{Immunofluorescence}

2- week old Dnmt3a flox/flox $; R 26-C A G-L S L-S u n 1-s f G F P-M y c^{+/}$;Viaat-Cre ${ }^{+/-}$and R26-CAG-LSL-Sun1sfGFP-Myc ${ }^{+/-} ;$Viaat-Cre ${ }^{+/-}$OR 6-week old Mecp $2^{\text {flox/Y }} ;$ R26-CAG-LSL-Sun1-sfGFP-Myc ${ }^{+/-}$;Viaat-Cre ${ }^{+/-}$ and R26-CAG-LSL-Sun1-sfGFP-Myc $c^{+/}$;Viaat-Cre ${ }^{+/-}$male were anaesthetize with Rodent Combo III and subject to transcardial perfusion using ice cold 1XPBS followed by PBS-buffered 4\% paraformaldehyde, $10 \mathrm{~mL}$ each. Brains were post-fixed in PBS-buffered $4 \%$ paraformaldehyde overnight at $4^{\circ} \mathrm{C}$, equilibrated in 30\% sucrose for 2 days and then frozen in Optimal Cutting Temperature medium (VWR 25608-930). For 2-week old brains, $25 \mu \mathrm{m}$ sagittal sections were taken on a Leica CM3050S cryostat, dried on slides and washed briefly in 1XPBS. Slides were transferred to antigen retrieval buffer (10mM Citrate pH6, $0.05 \%$ Tween-20) in a $95^{\circ} \mathrm{C}$ water bath for $20 \mathrm{~min}$, and then solution was allowed to cool to RT. For 6week old brains $25 \mu \mathrm{m}$ sagittal sections were taken on a Leica CM3050S cryostat and then processed further as floating sections. All sections were blocked in blocking buffer ( $2 \%$ normal goat serum, $0.3 \%$ Triton X-100, in 1XPBS) for $1 \mathrm{hr}$ at RT and then stained with respective primary antibodies in blocking buffer (1:250 anti-Dnmt3a (VWR 64B1446) and 1:200 anti-Myc (Sigma C3956) for 2-week old brains and 1:500 anti-MeCP2 (Cell signaling 3456) and 1:800 anti-GFP (abcam 13970) for 6-week old brains). Sections were washed $4 \mathrm{X}$ in $1 \mathrm{XTBST}$ at RT for $5 \mathrm{~min}$ each and then stained with secondary antibodies overnight at $4^{\circ} \mathrm{C}(1: 1000$ goat anti-mouse 555 (Invitrogen A21127) and 1:750 goat anti-rabbit 488 (Bethyl A120-201D2) for 2-week old brains and 1:750 goat anti-chicken 488 (Invitrogen A11039) and 1:1000 donkey anti Rabbit-568 (Invitrogen A10042) for 6-week old brains). Sections were washed 4x in 1XTBST at RT for 5min each and then stained with 2.5 $\mu$ g DAPI in 1XPBS then washed in 1XPBS, both for 10 minutes at RT. Sectioned were mounted in VECTASHIELD HardSet Antifade Mounting Medium without DAPI (Vector Laboratories H-1400) and let dry overnight. Images were taken on a Zeiss LSM 
880 with Airyscan microscope at $63 \mathrm{X}$. Images were taken with the same laser and gain settings and processed equivalently to facilitate comparison across genotypes. Of note, Dnmt3a related brains were processed at 2-weeks of age as Dnmt3a protein levels are at their peak, but then decline soon after this developmental time window(13) making Immunofluorescence challenging at 6-weeks of age.

\section{Electrophysiology}

Acute fresh brain slices were prepared from 6-week old mice. Coronal slices (350 $\mu \mathrm{m}$ thick) containing striatum were cut with a vibratome (Leica Microsystems Inc., Buffalo Grove, IL) in a chamber filled with cutting solution containing $110 \mathrm{mM} \mathrm{C}_{5} \mathrm{H}_{14} \mathrm{ClNO}, 25 \mathrm{mM} \mathrm{NaHCO}_{3}, 25 \mathrm{mM}$ D-glucose, $11.6 \mathrm{mM} \mathrm{C}_{6} \mathrm{H}_{7} \mathrm{O}_{6} \mathrm{Na}$, $7 \mathrm{mM} \mathrm{MgSO}_{4}, 3.1 \mathrm{mM} \mathrm{C}_{3} \mathrm{H}_{3} \mathrm{NaO}_{3}, 2.5 \mathrm{KCl}, 1.25 \mathrm{mM} \mathrm{NaH}_{2} \mathrm{PO}_{4}$ and $0.5 \mathrm{mM} \mathrm{CaCl}_{2}$. The slices were then incubated in artificial cerebrospinal fluid (ACSF) containing $119 \mathrm{mM} \mathrm{NaCl}, 26.2 \mathrm{mM} \mathrm{NaHCO}, 11 \mathrm{mM}$ Dglucose, $3 \mathrm{mM} \mathrm{KCl}, 2 \mathrm{mM} \mathrm{CaCl}_{2}, 1 \mathrm{mM} \mathrm{MgSO}_{4}, 1.25 \mathrm{mM} \mathrm{NaH}_{2} \mathrm{PO}_{4}$ at RT. The solutions were bubbled with $95 \% \mathrm{O}_{2}$ and $5 \% \mathrm{CO}_{2}$.

Whole-cell recording was made from medium spiny neurons in the dorsal striatum by using a patchclamp amplifier (MultiClamp 700B, Molecular Devices, Union City, CA) under infrared differential interference contrast optics. Microelectrodes were made from borosilicate glass capillaries and had a resistance of 2.5-4 M . Data was collected with a digitizer (DigiData 1440A, Molecular Devices). The analysis software pClamp10 (Molecular Devices) and Minianalysis 6.0.3 (Synaptosoft Inc., Decatur, GA) were used for data analysis. Miniature IPSCs were recorded in voltage-clamp mode in the presence of $10 \mu \mathrm{M}$ 6-cyano-7-nitroquinoxaline-2, 3-dione (CNQX), 50 $\mu \mathrm{M}$ D-2-amino-5-phosphonopentanoic acid (AP5) and $1 \mu \mathrm{M}$ TTX. The glass pipettes were filled with high-Cl-intrapipette solution containing $145 \mathrm{mM}$ $\mathrm{KCl}$, 10mM HEPES, 2mM MgCl2, 4mM MgATP, 0.3mM Na2GTP and 10mM Na2-phosphocreatine, $\mathrm{pH}$ 7.2 (with $\mathrm{KOH}$ ). Signals were filtered at $2 \mathrm{KHz}$ and sampled at $10 \mathrm{KHz}$. Data was discarded when the change in the series resistance was above $20 \%$ during the course of the experiment. The whole-cell recording was performed at $25( \pm 1)^{\circ} \mathrm{C}$ with the help of an automatic temperature controller (Warner Instruments, Hamden, CT). Data was analyzed with ordinary one-way ANOVA with Tukey's multiple comparisons. Results were considered to be significant at $\mathrm{p}<0.05$.

\section{Nuclei Isolation}

Whole striatum was dissected from Dnmt3 $a^{\text {flox/flox }} ;$ R26-CAG-LSL-Sun1-sfGFP-Myc $\mathrm{C}^{+/-}$; Viaat-Cre $\mathrm{C}^{+-}$, $M e c p 2^{\text {flox/y }} ; R 26-C A G-L S L-S u n 1-s f G F P-M y c^{+/-} ;{\text {Viaat }-C r e e^{+/} \text {, and R26-CAG-LSL-Sun1-sfGFP-Myc }}^{+/-}$ ;Viaat-Cre ${ }^{+-}$, male mice in ice-cold HB buffer (0.25M sucrose, $25 \mathrm{mM} \mathrm{KCL}, 5 \mathrm{mM} \mathrm{MgCl} 2,20 \mathrm{mM}$ 
Tricine- $\mathrm{NaOH}$ ) and flash frozen in liquid nitrogen and stored at $-80^{\circ} \mathrm{C}$. Experimental striatum (both halves of one mouse) were subjected to nuclear isolation and sorting for a total of 4 animals for each genotype. Individual striatum were dounced one at a time in $9 \mathrm{~mL}$ lysis buffer $(0.32 \mathrm{M}$ Sucrose, $5 \mathrm{mM}$ $\mathrm{CaCl} 2,3 \mathrm{mM} \mathrm{Mg}(\mathrm{Ac})_{2}, 0.1 \mathrm{mM}$ EDTA pH8, 10mM Tris-HCl pH8, 1mM DTT, 0.1\% Triton X-100, $1 \mathrm{X}$ protease inhibitors (Sigma 5056489001), ribonuclease inhibitor (Promega N261A) $30 \mathrm{U} / \mathrm{ml}$ in DEPC treated water) in a 15mL dounce homogenizer (VWR 62400-642) 15 strokes with loose pestle, followed by 35 strokes with tight pestle. Homogenized tissue was gently layered onto two ultracentrifuge tubes (4.5 $\mathrm{ml}$ on each) filled with $8.5 \mathrm{~mL}$ sucrose solution (1.8M sucrose, $3 \mathrm{mM} \mathrm{Mg}(\mathrm{Ac})_{2}, 1 \mathrm{mM}$ DTT, $10 \mathrm{mM}$ Tris$\mathrm{HCl} \mathrm{pH8,} \mathrm{1X} \mathrm{protease} \mathrm{inhibitors} \mathrm{(Sigma} \mathrm{5056489001),} \mathrm{ribonuclease} \mathrm{inhibitor} 30 \mathrm{U} / \mathrm{ml}$ in DEPC treated water). Samples were spun in a Beckman Optima LE $80 \mathrm{~K}$ ultracentrifuge for $2.5 \mathrm{hrs}$ at $6^{\circ} \mathrm{C}$ with slow deceleration. After centrifugation, the top layer of gradient and mitochondrial layer was discarded carefully with vacuum until $\sim 3 \mathrm{~mL}$ remained. Remaining solution was gently poured off and tubes dabbed with a KimWipe being careful to not disturb the nuclear pellet. Nuclei were rehydrated on ice for $45 \mathrm{~min}$ in $500 \mathrm{uL}$ of rehydration buffer that was added drop-wise $(0.5 \% \mathrm{BSA}$, $1 \mathrm{X}$ protease inhibitors, ribonuclease inhibitor $30 \mathrm{U} / \mathrm{ml}$ in $1 \mathrm{X}$ DPBS). Re-hydrated nuclei were pipetted up and down 50X with using a $1 \mathrm{~mL}$ filter tip with the end cut to increase clearance size. Matched samples were then re-pooled and dual labeled with mouse anti-NeuN 647 (Millipore MAB377 labeled using Thermo Fisher Scientific A10475) and anti-GFP 488 (Thermo Fisher Scientific A-21311) at 1:300 and 1:1000 ratio, respectively, for 1hr at $4^{\circ} \mathrm{C}$ with gentle mixing. A BD Influx ${ }^{\mathrm{TM}}$ Cell Sorter at the Salk Flow Cytometry Core facility equipped with a 100 micron nozzle tip was used to isolate nuclei. Sheath fluid and pressure was 1 XPBS (no Ca2 ${ }^{+}$, $\left.\mathrm{Mg}^{+}\right)$and 18.5PSI, respectively. Nuclei were first gated based on light scatter properties to exclude debris (forward versus side scatter) then aggregate exclusion gating was applied (forward scatter as well as side scatter pulse width). Finally, nuclei were selected based on anti-NeuN647 and anti-GFP488 labeling. The nuclei fractions were collected at $4^{\circ} \mathrm{C}$ using a 1 or 2 drop purity sort mode and collected into rehydration buffer described above. Nuclei were then spun down at $5,000 \mathrm{rpm}$ for $15 \mathrm{~min}$ at $4^{\circ} \mathrm{C}$, solution removed until $\sim 50-100 \mathrm{uL}$ of buffer was left, and frozen on dry ice and stored at $-80^{\circ} \mathrm{C}$ until DNA/RNA extraction for NGS library preparation.

\section{RNA extraction, NGS library preparation and RNA-seq}

RNA was extracted from sorted nuclei using a single cell RNA purification kit from Norgen Biotek according to manufactures instructions and stored at $-80 \mathrm{C}$ until library preparation at the Genomic and RNA Profiling Core at Baylor College of Medicine. The Genomic and RNA Profiling Core first conducted Sample Quality checks using the NanoDrop spectrophotometer and Agilent Bioanalyzer 2100. Total RNA was quanted by the user using Qubit 2.0 RNA quantitation assay. The NuGEN Ovation RNA- 
Seq v2 (protocol p/n 7102, kit p/n 7102-08) and the Rubicon ThruPlex DNA-Seq (protocol: QAM-108002, kit p/n R400428) kits were used for library preparation as follows:

\section{NuGEN Ovation RNA-Seq System v2 Protocol}

Purified double-stranded cDNA was generated from approximately 5ng of total RNA and amplified using both oligo $\mathrm{d}(\mathrm{T})$ and random primers. Samples were quantified using the NanoDrop ND-2000 spectrophotometer and Qubit 2.0 DNA quantitation assay. One microgram of each sample's ds-cDNA was sheared using the Covaris LE220 focused-ultrasonicator with a 400bp target size. The sheared samples were quantified using the Qubit 2.0 DNA quantitation assay. The fragment sizes were viewed on the Agilent Bioanalyzer to verify proper shearing.

\section{Rubicon ThruPlex DNA-Seq Library Preparation Protocol}

A double-stranded DNA library was generated from 50ng of sheared, double-stranded cDNA, preparing the fragments for hybridization onto a flowcell. This is achieved by first creating blunt ended fragments, then ligating stem-loop adapters with blocked 5' ends to the 5' end of the double-stranded cDNA, leaving a nick at the 3' end. Finally, library synthesis extends the 3' end of the double stranded cDNA and Illumina-compatible indexes are incorporated with 5 amplification cycles. The fragments are purified using AMPure XP Bead system. The resulting libraries are quantitated using the NanoDrop ND1000 spectrophotometer and fragment size assessed with the Agilent Bioanalyzer. A qPCR quantitation is performed on the libraries to determine the concentration of adapter-ligated fragments using the Applied Biosystems ViiA7 TM Real-Time PCR System and a KAPA Library Quant Kit.

\section{Cluster Generation by Bridge Amplification}

Using the concentration from the ViiA7 qPCR machine above, $25 \mathrm{pM}$ from each equimolarly pooled library was loaded onto five lanes of a high output $\mathrm{v} 4$ flowcell (Illumina $\mathrm{p} / \mathrm{n}$ PE-401-4001) and amplified by bridge amplification using the Illumina cBot machine (cBot protocol:

PE_HiSeq_Cluster_Kit_v4_cBot_recipe_v9.0). PhiX Control v3 adapter-ligated library (Illumina p/n 15017666 ) is spiked-in at $2 \%$ by weight to ensure balanced diversity and to monitor clustering and sequencing performance. A paired-end 100 cycle run was used to sequence the flowcell on a HiSeq 2500 Sequencing System (Illumina p/n FC-401-4003).

\section{RNA-seq analysis}

Adapter sequences were removed from raw sequencing reads using cutadapt (v1.13), trimmed reads were then aligned to reference genome GRCm38 (GENCODE vM15 Primary assembly) using STAR 
aligner(64) (version 2.5.3a) using default parameters. The number of reads aligned within the gene body (from TSS to TES) of each gene was tabulated using FeatureCount (65) (v1.5.3) (without extension on both ends). Finally, differential gene expression (DEG) analyses on the read counts were performed using DESeq2(66) (v1.6.2) in R environment. Genes with total read counts less 10 were filtered out from analysis. For analysis of differentially expressed genes split according to gene length as measured from transcription start site to transcription end site. Genes were defined as long or short according to length standards defined in Gabel et al(17).

\section{DNA Methylation Sequencing}

DNA methylome libraries were generated using a modified snmC-seq method adapted for bulk DNA samples and as previous described in Sabbagh et al(67).1\% unmethylated lambda DNA (Promega D1521) was added into each sample. Libraries were sequenced using an Illumina HiSeq 4000 instrument. The mapping of DNA methylome reads was done also described in Sabbagh et al(67).

Plots of $\mathrm{mCH}$ versus $\mathrm{mCG}$ in wild-type mice are made with gene body methylation values for percentage $\mathrm{mCH}$ or percentage $\mathrm{mCG}$. All genes are plotted as one point per gene. Density contours are plotted with geom_density_2d in R and Pearson correlations were calculated with the cor function. The plots for the methylation differences are calculated with $((\% \mathrm{mCH}$ in $\mathrm{WT})-(\% \mathrm{mCH}$ in $\mathrm{cKO}))$ or as $((\%$ $\mathrm{mCG}$ in $\mathrm{WT})$ - (\% mCG in $\mathrm{cKO}))$.

\section{Integrative RNA-seq and methylation analysis}

Methylation versus gene expression plots were made using running average binning on significantly differentially expressed genes (DEGs, padj $<0.01$ ). To obtain bins, genes were first ordered based on their methylation value. Methylation is calculated as $((\% \mathrm{mCH}$ in $\mathrm{WT})-(\% \mathrm{mCH}$ in $\mathrm{cKO}))$ or as $((\%$ $\mathrm{mCG}$ in $\mathrm{WT})$ - (\% mCG in cKO)). Genes were then binned such that each bin contained the same number of genes, with 80 percent overlap between consecutive bins. One point is plotted per bin. For the plots of genes significantly misregulated only in the Dnmt3a cKO model, each bin has 25 genes and the window moves by 5 genes per bin. For plots of genes significantly misregulated only in the Mecp $2 \mathrm{cKO}$ model, as well as the common DEGs, the bin size is 10 genes and the window slides by 2 each time. The number of bins obtained for DEGs in the Dnmt3a cKO model were 121, and 42 for DEGs that were only significant in the Dnmt3a cKO model, and common DEGs, respectively. The number of bins obtained for DEGs in the Mecp 2 cKO model were 62, and 42 for DEGs that were only significant in the Mecp 2 cKO model, and common DEGs, respectively. After binning, a univariate linear model was fit to the data with the $1 \mathrm{~m}$ function in $\mathrm{R}$, and the $\mathrm{R}^{2}$ (percentage variance in $\log 2$ fold change explained by methylation) was 
calculated.

To examine the significance of the observed trends in the running average plots, we compared their $R^{2}$ values to $R^{2}$ values from 1,000 random gene repetitions, with each repetition containing the same number of non-differentially expressed genes (padj > 0.01). Grey points represent each iteration of this process, with the original DEG (padj < 0.01$)$ values for $\mathrm{R}^{2}$ shown in larger orange, green, or blue points. $\mathrm{P}$ value was then computed as $(r+1) /(n+1)(68) ; \mathrm{r}$ is number of repetitions where $\mathrm{R}^{2}$ is greater than that in the DEGs, and $\mathrm{n}$ is total number of repetitions.

\section{Acknowledgments}

We are grateful to members of the Zoghbi lab for helpful discussions, Drs. H. K. Yalamanchili and HH. Jeong for assistance with integrative analysis of RNA-seq and methylation data, and V.L. Brandt for critical comments on the manuscript. We thank Drs. Michael Greenberg and Hume Stroud for assistance with access to and discussion of published single-nuclei RNA-seq data. We thank the Neurovisualization and Neurobehavioral Cores at the Jan and Dan Duncan Neurological Research Institute at Texas Children's Hospital and the BCM-IDDRC (U.S. NIH Grant U54HD083092). This project was supported by NIH/NINDS 5R01NS057819-13 (HYZ), NIH/ NIMH R01MH112763 (MMB and JRE), the Genomic and RNA Profiling Core at Baylor College of Medicine, and the Flow Cytometry Core Facility of the Salk Institute with funding from NIH-NCI CCSG: P30 014195. LAL is a Howard Hughes Medical Institute Fellow of the Life Sciences Research Foundation. HYZ and JRE are investigators with the Howard Hughes Medical Institute.

\section{Declaration of Interests}

The authors declare no competing interests.

\section{Author Contributions}

LAL and HYZ conceived of the study. LAL and KU collected and analyzed behavioral data. WW and JL collected and analyzed electrophysiology data. LAL and JL collected and processed samples for RNA and methylation sequencing. RC prepared and JRN sequenced methylation libraries. YW processed and analyzed RNA-seq data. CL processed and analyzed genomic methylation data. AT made mCH versus mCG plots and preformed integrative RNA-seq and methylation analysis. MAD assisted in tissue collection. LAL and HYZ wrote the manuscript. LAL, KU, YW, CL, WW, MAD, ZDL, MAG, JRE, MMB and HYZ interpreted data, edited manuscript and all authors approved of the final version. 


\section{Data Access}

DNA methylome data can be accessed through a web browser at http://neomorph.salk.edu/Striatum Inhibitory Neuron.php and at the Gene Expression Omnibus database (GEO) at accession number GSE124009.

RNA-seq data can be accessed at GEO at accession number GSE12394.

\section{References}

1. Hotchkiss RD. The quantitative separation of purines, pyrimidines, and nucleosides by paper chromatography. Journal of Biological Chemistry. 1948 Aug;175(1):315-32.

2. Compere SJ, Palmiter RD. DNA methylation controls the inducibility of the mouse metallothionein-I gene lymphoid cells. Cell. 1981 Jul;25(1):233-40.

3. Li E, Zhang Y. DNA methylation in mammals. Cold Spring Harbor Perspectives in Biology. 2014 May 1;6(5):a019133.

4. Shen L, Song C-X, He C, Zhang Y. Mechanism and function of oxidative reversal of DNA and RNA methylation. Annu Rev Biochem. 2014;83(1):585-614.

5. Aran D, Toperoff G, Rosenberg M, Hellman A. Replication timing-related and gene body-specific methylation of active human genes. Hum Mol Genet. 2011 Feb 15;20(4):670-80.

6. Ball MP, Li JB, Gao Y, Lee J-H, LeProust EM, Park I-H, et al. Targeted and genome-scale strategies reveal gene-body methylation signatures in human cells. Nat Biotechnol. 2009 Apr;27(4):361-8.

7. Hellman A, Chess A. Gene body-specific methylation on the active X chromosome. Science. 2007 Feb 23;315(5815):1141-3.

8. Keown CL, Berletch JB, Castanon R, Nery JR, Disteche CM, Ecker JR, et al. Allele-specific nonCG DNA methylation marks domains of active chromatin in female mouse brain. Proc Natl Acad Sci USA. 2017 Apr 4;114(14):E2882-90.

9. Lister R, Pelizzola M, Dowen RH, Hawkins RD, Hon G, Tonti-Filippini J, et al. Human DNA methylomes at base resolution show widespread epigenomic differences. Nature. 2009 Nov 19;462(7271):315-22.

10. Ramsahoye BH, Biniszkiewicz D, Lyko F, Clark V, Bird AP, Jaenisch R. Non-CpG methylation is prevalent in embryonic stem cells and may be mediated by DNA methyltransferase 3a. PNAS. 2000 May 9;97(10):5237-42.

11. Schultz MD, He Y, Whitaker JW, Hariharan M, Mukamel EA, Leung D, et al. Human body epigenome maps reveal noncanonical DNA methylation variation. Nature. 2015 Jul 9;523(7559):212-6. 
12. He Y, Ecker JR. Non-CG Methylation in the Human Genome. Annu Rev Genomics Hum Genet. 2015;16(1):55-77.

13. Lister R, Mukamel EA, Nery JR, Urich M, Puddifoot CA, Johnson ND, et al. Global epigenomic reconfiguration during mammalian brain development. Science. 2013 Aug 9;341(6146):12379055 .

14. Price AJ, Collado-Torres L, Ivanov NA, Xia W, Burke EE, Shin JH, et al. Divergent neuronal DNA methylation patterns across human cortical development reveal critical periods and a unique role of CpH methylation. Genome Biol. 2019 Sep 26;20(1):196.

15. He Y, Hariharan M, Gorkin DU, Dickel DE, Luo C, Castanon RG, et al. Spatiotemporal DNA Methylome Dynamics of the Developing Mammalian Fetus. 2017;19:2383.

16. Jurkowska RZ, Jeltsch A. Enzymology of Mammalian DNA Methyltransferases. Adv Exp Med Biol. 2016;945:87-122.

17. Gabel HW, Kinde B, Stroud H, Gilbert CS, Harmin DA, Kastan NR, et al. Disruption of DNAmethylation-dependent long gene repression in Rett syndrome. Nature. 2015 Jun 4;522(7554):8993.

18. Guo JU, Su Y, Shin JH, Shin J, Li H, Xie B, et al. Distribution, recognition and regulation of nonCpG methylation in the adult mammalian brain. Nat Neurosci. 2014 Feb;17(2):215-22.

19. Stroud H, Su SC, Hrvatin S, Greben AW, Renthal W, Boxer LD, et al. Early-Life Gene Expression in Neurons Modulates Lasting Epigenetic States. Cell. 2017 Nov 16;171(5):1151-1164.e16.

20. Tatton-Brown K, Seal S, Ruark E, Harmer J, Ramsay E, Del Vecchio Duarte S, et al. Mutations in the DNA methyltransferase gene DNMT3A cause an overgrowth syndrome with intellectual disability. Nat Genet. 2014 Apr;46(4):385-8.

21. Sanders SJ, He X, Willsey AJ, Ercan-Sencicek AG, Samocha KE, Cicek AE, et al. Insights into Autism Spectrum Disorder Genomic Architecture and Biology from 71 Risk Loci. Neuron. 2015 Sep 23;87(6):1215-33.

22. Heyn P, Logan CV, Fluteau A, Challis RC, Auchynnikava T, Martin C-A, et al. Gain-of-function DNMT3A mutations cause microcephalic dwarfism and hypermethylation of Polycomb-regulated regions. Nat Genet. 2019 Jan;51(1):96-105.

23. Chen, Chen K, Lavery LA, Baker SA, Shaw CA, Li W, et al. MeCP2 binds to non-CG methylated DNA as neurons mature, influencing transcription and the timing of onset for Rett syndrome. Proc Natl Acad Sci USA. 2015 Apr 28;112(17):5509-14.

24. Amir RE, Van den Veyver IB, Wan M, Tran CQ, Francke U, Zoghbi HY. Rett syndrome is caused by mutations in X-linked MECP2, encoding methyl-CpG-binding protein 2. Nat Genet. 1999 Oct;23(2):185-8.

25. Leonard H, Cobb S, Downs J. Clinical and biological progress over 50 years in Rett syndrome. Nat Rev Neurol. 2017 Jan;13(1):37-51. 
26. Zoghbi HY. Rett Syndrome and the Ongoing Legacy of Close Clinical Observation. Cell. 2016 Oct 6;167(2):293-7.

27. Young JI, Zoghbi HY. X-chromosome inactivation patterns are unbalanced and affect the phenotypic outcome in a mouse model of rett syndrome. Am J Hum Genet. 2004 Mar;74(3):51120 .

28. Lombardi LM, Baker SA, Zoghbi HY. MECP2 disorders: from the clinic to mice and back. J Clin Invest. 2015 Aug 3;125(8):2914-23.

29. Chen RZ, Akbarian S, Tudor M, Jaenisch R. Deficiency of methyl-CpG binding protein-2 in CNS neurons results in a Rett-like phenotype in mice. Nat Genet. 2001 Mar;27(3):327-31.

30. Gemelli T, Berton O, Nelson ED, Perrotti LI, Jaenisch R, Monteggia LM. Postnatal loss of methyl-CpG binding protein 2 in the forebrain is sufficient to mediate behavioral aspects of Rett syndrome in mice. Biol Psychiatry. 2006 Mar 1;59(5):468-76.

31. Fyffe SL, Neul JL, Samaco RC, Chao H-T, Ben-Shachar S, Moretti P, et al. Deletion of Mecp2 in Sim1-expressing neurons reveals a critical role for $\mathrm{MeCP} 2$ in feeding behavior, aggression, and the response to stress. Neuron. 2008 Sep 25;59(6):947-58.

32. Samaco RC, Mandel-Brehm C, Chao H-T, Ward CS, Fyffe-Maricich SL, Ren J, et al. Loss of $\mathrm{MeCP} 2$ in aminergic neurons causes cell-autonomous defects in neurotransmitter synthesis and specific behavioral abnormalities. Proc Natl Acad Sci USA. 2009 Dec 22;106(51):21966-71.

33. Chao H-T, Chen H, Samaco RC, Xue M, Chahrour M, Yoo J, et al. Dysfunction in GABA signalling mediates autism-like stereotypies and Rett syndrome phenotypes. Nature. 2010 Nov 11;468(7321):263-9.

34. Ito-Ishida A, Ure K, Chen H, Swann JW, Zoghbi HY. Loss of MeCP2 in Parvalbumin-and Somatostatin-Expressing Neurons in Mice Leads to Distinct Rett Syndrome-like Phenotypes. Neuron. 2015 Nov 18;88(4):651-8.

35. Meng X, Wang W, Lu H, He L-J, Chen W, Chao ES, et al. Manipulations of MeCP2 in glutamatergic neurons highlight their contributions to Rett and other neurological disorders. Elife. 2016 Jun 21;5:185.

36. Zhang W, Peterson M, Beyer B, Frankel WN, Zhang Z-W. Loss of MeCP2 from forebrain excitatory neurons leads to cortical hyperexcitation and seizures. J Neurosci. 2014 Feb 12;34(7):2754-63.

37. Wang X, Lacza Z, Sun YE, Han W. Leptin resistance and obesity in mice with deletion of methylCpG-binding protein 2 (MeCP2) in hypothalamic pro-opiomelanocortin (POMC) neurons. Diabetologia. 2014 Jan;57(1):236-45.

38. Goffin D, Brodkin ES, Blendy JA, Siegel SJ, Zhou Z. Cellular origins of auditory event-related potential deficits in Rett syndrome. Nat Neurosci. 2014 Jun;17(6):804-6.

39. Ward CS, Arvide EM, Huang T-W, Yoo J, Noebels JL, Neul JL. MeCP2 is critical within HoxB1derived tissues of mice for normal lifespan. J Neurosci. 2011 Jul 13;31(28):10359-70. 
40. Adachi M, Autry AE, Covington HE, Monteggia LM. MeCP2-mediated transcription repression in the basolateral amygdala may underlie heightened anxiety in a mouse model of Rett syndrome. $\mathrm{J}$ Neurosci. 2009 Apr 1;29(13):4218-27.

41. Guy J, Hendrich B, Holmes M, Martin JE, Bird A. A mouse Mecp2-null mutation causes neurological symptoms that mimic Rett syndrome. Nat Genet. 2001 Mar;27(3):322-6.

42. Ross PD, Guy J, Selfridge J, Kamal B, Bahey N, Tanner KE, et al. Exclusive expression of $\mathrm{MeCP} 2$ in the nervous system distinguishes between brain and peripheral Rett syndrome-like phenotypes. Hum Mol Genet. 2016 Oct 15;25(20):4389-404.

43. McGraw CM, Samaco RC, Zoghbi HY. Adult neural function requires MeCP2. Science. 2011 Jul 8;333(6039):186-6.

44. Cheval H, Guy J, Merusi C, De Sousa D, Selfridge J, Bird A. Postnatal inactivation reveals enhanced requirement for MeCP2 at distinct age windows. Hum Mol Genet. 2012 Sep 1;21(17):3806-14.

45. Mo A, Mukamel EA, Davis FP, Luo C, Henry GL, Picard S, et al. Epigenomic Signatures of Neuronal Diversity in the Mammalian Brain. Neuron. 2015 Jun 17;86(6):1369-84.

46. Kaneda M, Okano M, Hata K, Sado T, Tsujimoto N, Li E, et al. Essential role for de novo DNA methyltransferase Dnmt3a in paternal and maternal imprinting. Nature. 2004 Jun 24;429(6994):900-3.

47. Oh W-J, Noggle SA, Maddox DM, Condie BG. The mouse vesicular inhibitory amino acid transporter gene: expression during embryogenesis, analysis of its core promoter in neural stem cells and a reconsideration of its alternate splicing. Gene. 2005 May 23;351:39-49.

48. Dudman JT, Gerfen CR. The Basal Ganglia. In: The Rat Nervous System. Academic Press; 2015. pp. 391-440.

49. Kemp JM, Powell TP. The structure of the caudate nucleus of the cat: light and electron microscopy. Philos Trans R Soc Lond, B, Biol Sci. 1971 Sep 30;262(845):383-401.

50. Lagger S, Connelly JC, Schweikert G, Webb S, Selfridge J, Ramsahoye BH, et al. MeCP2 recognizes cytosine methylated tri-nucleotide and di-nucleotide sequences to tune transcription in the mammalian brain. PLoS Genet. 2017 May;13(5):e1006793.

51. Okano M, Bell DW, Haber DA, Li E. DNA methyltransferases Dnmt3a and Dnmt3b are essential for de novo methylation and mammalian development. Cell. 1999 Oct 29;99(3):247-57.

52. Nguyen S, Meletis K, Fu D, Jhaveri S, Jaenisch R. Ablation of de novo DNA methyltransferase Dnmt3a in the nervous system leads to neuromuscular defects and shortened lifespan. Dev Dyn. 2007 Jun;236(6):1663-76.

53. Kohno D, Lee S, Harper MJ, Kim KW, Sone H, Sasaki T, et al. Dnmt3a in Sim1 neurons is necessary for normal energy homeostasis. J Neurosci. 2014 Nov 12;34(46):15288-96. 
54. Morris MJ, Adachi M, Na ES, Monteggia LM. Selective role for DNMT3a in learning and memory. Neurobiol Learn Mem. 2014 Nov;115:30-7.

55. Feng J, Zhou Y, Campbell SL, Le T, Li E, Sweatt JD, et al. Dnmt1 and Dnmt3a maintain DNA methylation and regulate synaptic function in adult forebrain neurons. Nat Neurosci. 2010 Apr;13(4):423-30.

56. Liu K, Xu C, Lei M, Yang A, Loppnau P, Hughes TR, et al. Structural basis for the ability of MBD domains to bind methyl-CG and TG sites in DNA. J Biol Chem. 2018 May 11;293(19):7344-54.

57. Luo C, Hajkova P, Ecker JR. Dynamic DNA methylation: In the right place at the right time. Science. 2018 Sep 28;361(6409):1336-40.

58. Kribelbauer JF, Laptenko O, Chen S, Martini GD, Freed-Pastor WA, Prives C, et al. Quantitative Analysis of the DNA Methylation Sensitivity of Transcription Factor Complexes. Cell Rep. 2017 Jun 13;19(11):2383-95.

59. Yin Y, Morgunova E, Jolma A, Kaasinen E, Sahu B, Khund-Sayeed S, et al. Impact of cytosine methylation on DNA binding specificities of human transcription factors. Science. 2017 May 5;356(6337):eaaj2239.

60. Wu H, Coskun V, Tao J, Xie W, Ge W, Yoshikawa K, et al. Dnmt3a-dependent nonpromoter DNA methylation facilitates transcription of neurogenic genes. Science. $2010 \mathrm{Jul}$ 23;329(5990):444-8.

61. Lomvardas S, Maniatis T. Histone and DNA Modifications as Regulators of Neuronal Development and Function. Cold Spring Harbor Perspectives in Biology. $2016 \mathrm{Jul}$ 1;8(7):a024208.

62. O'Malley RC, Huang S-SC, Song L, Lewsey MG, Bartlett A, Nery JR, et al. Cistrome and Epicistrome Features Shape the Regulatory DNA Landscape. Cell. 2016 May 19;165(5):1280-92.

63. Guy J, Gan J, Selfridge J, Cobb S, Bird A. Reversal of neurological defects in a mouse model of Rett syndrome. Science. 2007 Feb 23;315(5815):1143-7.

64. Dobin A, Davis CA, Schlesinger F, Drenkow J, Zaleski C, Jha S, et al. STAR: ultrafast universal RNA-seq aligner. Bioinformatics. 2013 Jan 1;29(1):15-21.

65. Liao Y, Smyth GK, Shi W. featureCounts: an efficient general purpose program for assigning sequence reads to genomic features. Bioinformatics. 2014 Apr 1;30(7):923-30.

66. Love MI, Huber W, Anders S. Moderated estimation of fold change and dispersion for RNA-seq data with DESeq2. Genome Biol. 2014;15(12):550.

67. Sabbagh MF, Heng JS, Luo C, Castanon RG, Nery JR, Rattner A, et al. Transcriptional and epigenomic landscapes of CNS and non-CNS vascular endothelial cells. Elife. 2018 Sep 6;7:505.

68. North BV, Curtis D, Sham PC. A note on the calculation of empirical P values from Monte Carlo procedures. Am J Hum Genet. 2002 Aug;71(2):439-41. 
bioRxiv preprint doi: https://doi.org/10.1101/815639; this version posted October 22, 2019. The copyright holder for this preprint (which was not certified by peer review) is the author/funder, who has granted bioRxiv a license to display the preprint in perpetuity. It is made available under aCC-BY-NC-ND 4.0 International license.

\section{Figures and legends}

Figure 1

Lavery et al.

\begin{tabular}{|lllll|}
\hline \multicolumn{3}{|c|}{ Control Genotypes } & & \\
\hline OWT & Cre & Flox & Het & OcKO \\
\hline
\end{tabular}

A

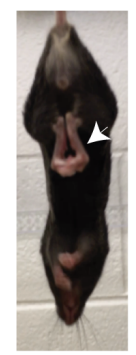

B

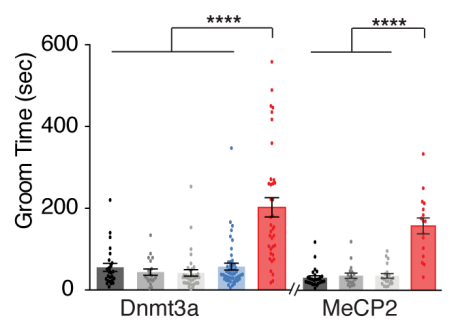

C

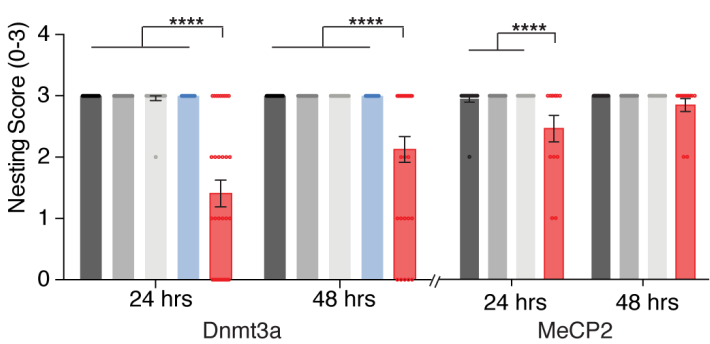

D

Grip Strength
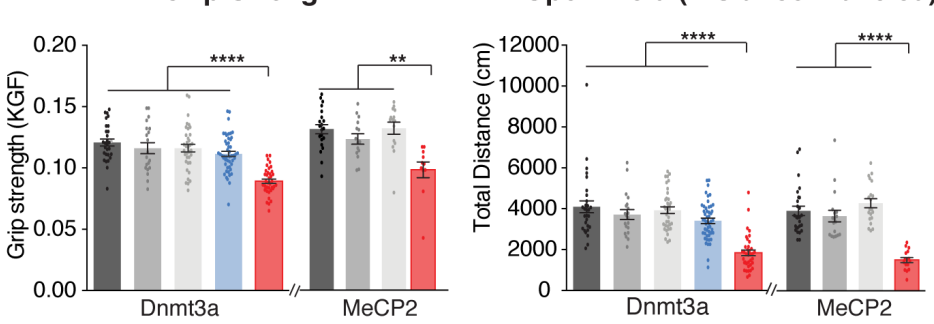

F Fear conditioning (Context)

G Examples of self-injury
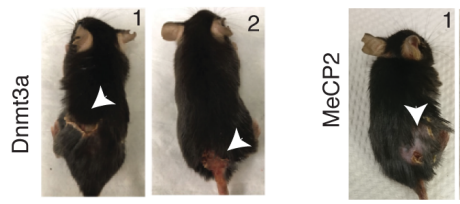

I

mIPSC (Amplitude)
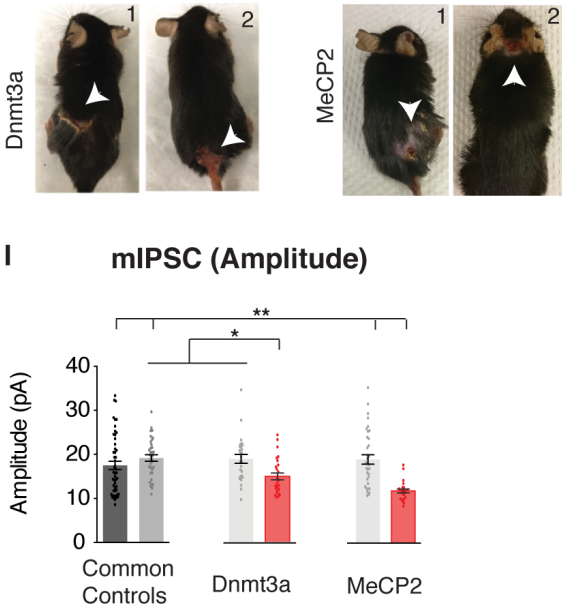

H

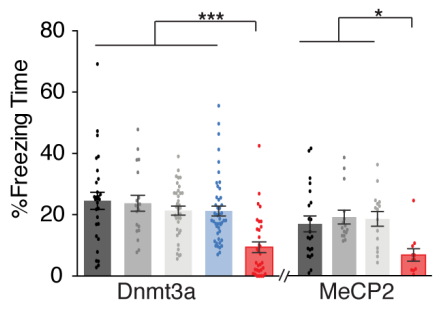

mIPSC (striatum)

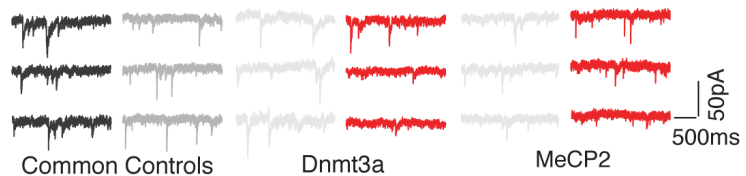

J

Body Weight

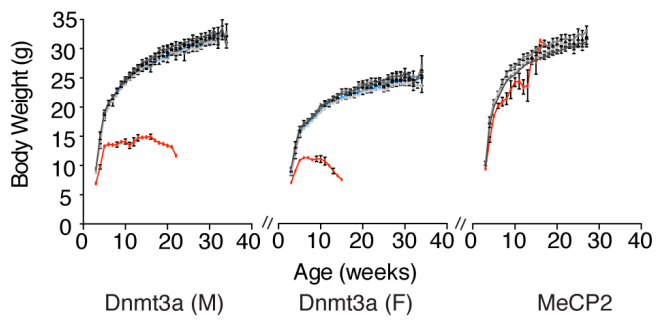

K Acoustic Startle Response

L

Parallel Rod Footslip M

Survival from lesioning
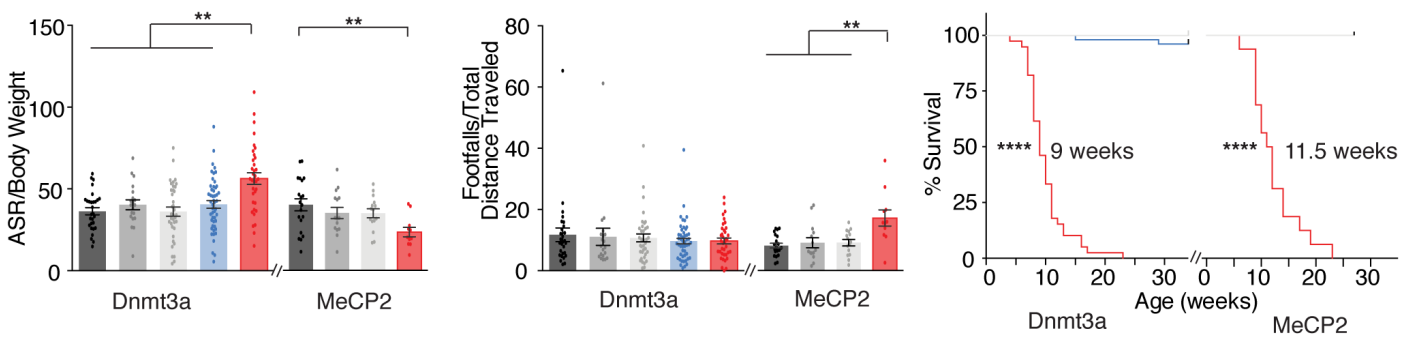
Table 1. Summary of behavioral and physiological test results in cKO models.

\begin{tabular}{|c|c|c|}
\hline $\begin{array}{l}\text { Symptom } \\
\text { Category }\end{array}$ & Test/observation & Result \\
\hline \multirow[t]{2}{*}{ General Health } & Reduced body weight & Dnmt3a \\
\hline & Prematurely moribund (humane end due to lesioning) & both \\
\hline Spasticity & Hind limb clasping & both \\
\hline \multirow{2}{*}{$\begin{array}{l}\text { Repetitive } \\
\text { Behavior }\end{array}$} & Forepaw stereotypies & Dnmt3a \\
\hline & Perseverative grooming \& self-injury & both \\
\hline \multirow[t]{2}{*}{ Nociceptive pain } & Delayed response to hot plate & both \\
\hline & Delayed response to tail flick & Dnmt $3 a$ \\
\hline Apraxia & Poor nest building & both \\
\hline Muscle Strength & Decreased grip strength & both \\
\hline \multirow[t]{4}{*}{ Motor } & Rotarod & none \\
\hline & Parallel rod footslip- more footslips & Mecp2 \\
\hline & Open field - decreased distance traveled & both \\
\hline & Open field-decreased vertical activity & both \\
\hline \multirow[t]{3}{*}{ Anxiety } & Open field - time spent in center & none \\
\hline & Elevated plus maze- increased time in open arms & Mecp2 \\
\hline & Light/dark box & none \\
\hline \multirow{3}{*}{$\begin{array}{l}\text { Learning and } \\
\text { Memory }\end{array}$} & Conditioned fear - decreased contextual fear response & both \\
\hline & Conditioned fear - cued & none \\
\hline & $\begin{array}{l}\text { Conditioned fear - decreased response to tone } \# 2 \text { during fear } \\
\text { learning (training) }\end{array}$ & Dnmt3a \\
\hline \multirow[t]{2}{*}{ Sensory processing } & Increased acoustic startle response & Dnmt3a \\
\hline & Paired pulse inhibition & none \\
\hline Social Behavior & Partition & none \\
\hline $\begin{array}{l}\text { Inhibitory } \\
\text { signaling }\end{array}$ & Altered miniature inhibitory postsynaptic currents & both \\
\hline
\end{tabular}


bioRxiv preprint doi: https://doi.org/101101/815639; this version posted October 22, 2019. The copyright holder for this preprint (which was not certified by peer review) is the author/funder, who has granted bioRxiv a license to display the preprint in perpetuity. It is made available under aCC-BY-NC-ND 4.0 International license.

Figure 2

Lavery et al.

A

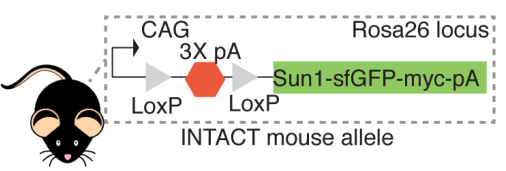

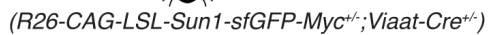

dissect striatum $\downarrow$ Viaat-positive neurons

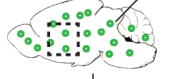

homogenize $\frac{1}{\frac{1}{\tau}} \quad$ Viaat-positive nuclei from striatum with GFP labeled membrane<smiles>O=[N+]([O-])O[C@H]1CC2CCC(C2)[C@H]1O</smiles>

Laserngarms $\begin{gathered}\text { Sort dual labeled nuclei } \\ (\text { GFP-488, NeuN-647) }\end{gathered}$

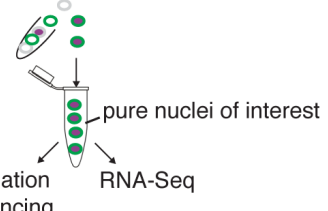

C

$$
\text { Methylation }
$$$$
\text { Sequencing }
$$

RNA-Se

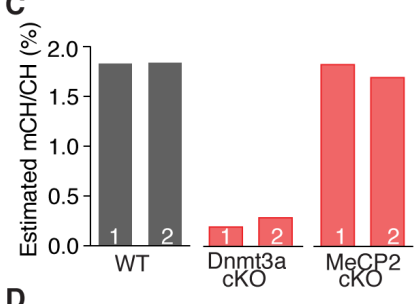

D

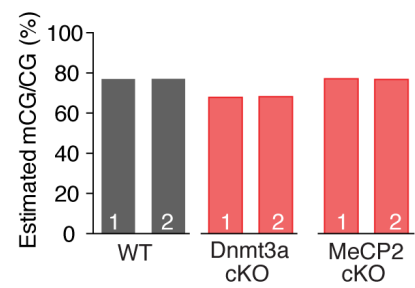

E

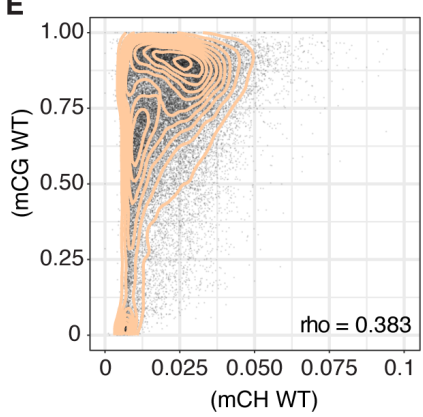

$F$
B
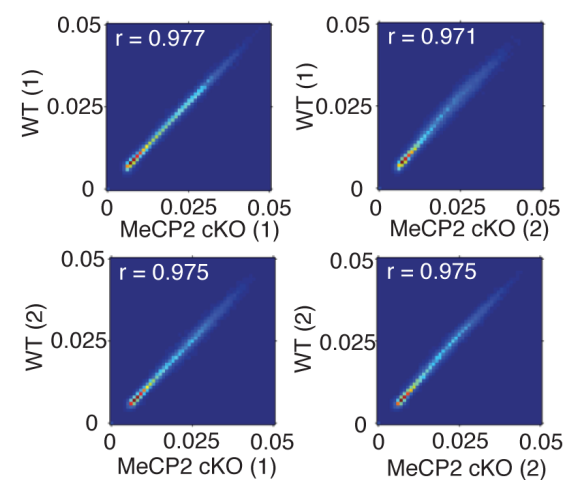

Biological replicates
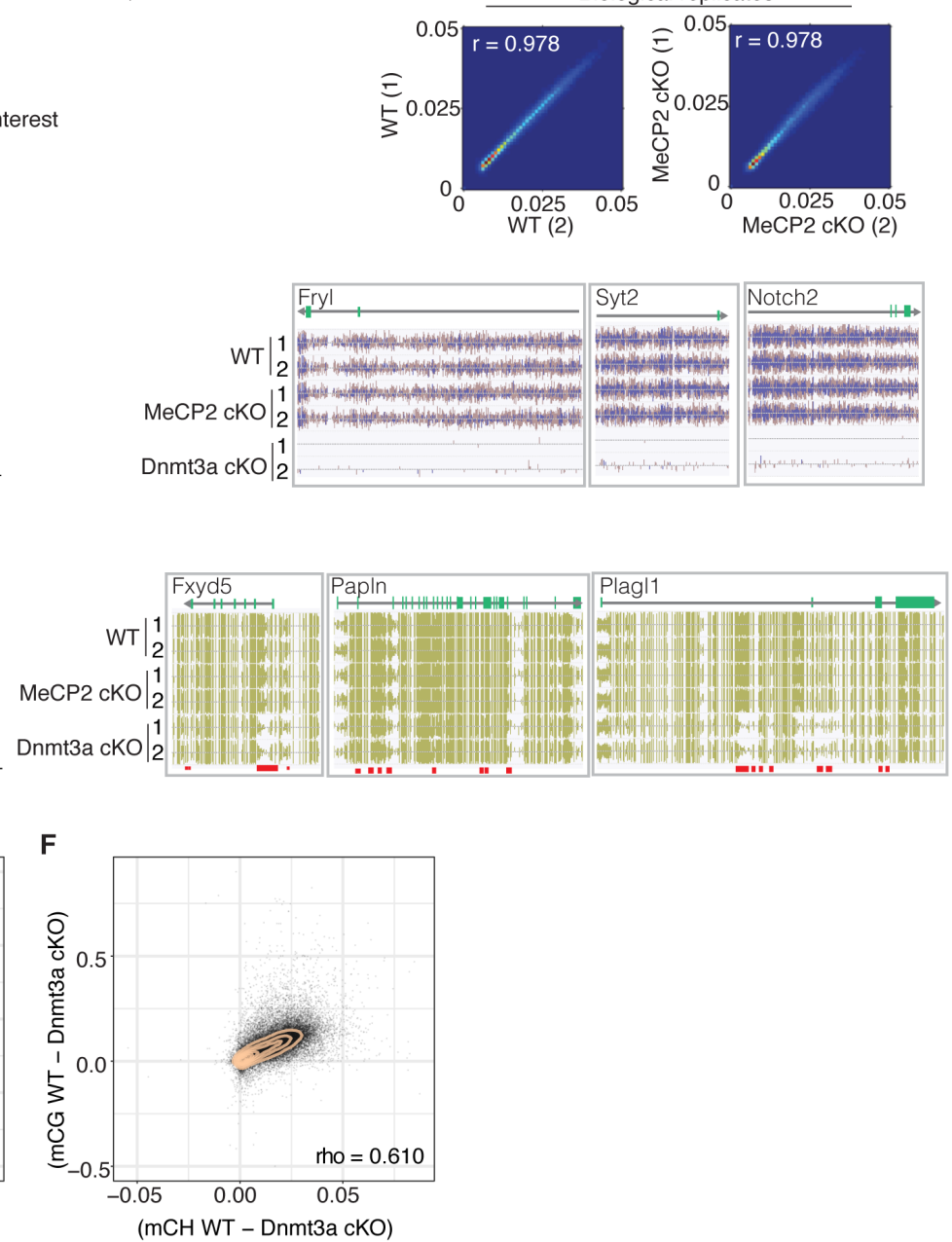
bioRxiv preprint doi: https://doi.org/10.1101/815639; this version posted October 22, 2019. The copyright holder for this preprint (which was not certified by peer review) is the author/funder, who has granted bioRxiv a license to display the preprint in perpetuity. It is made available under aCC-BY-NC-ND 4.0 International license.

Figure 3

A

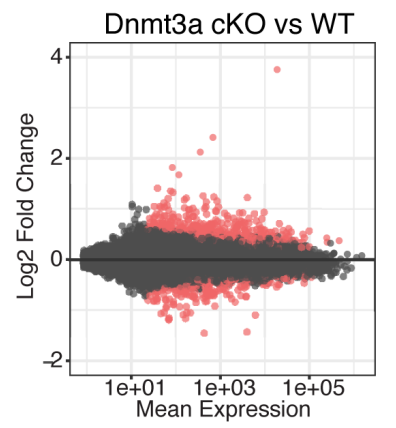

B

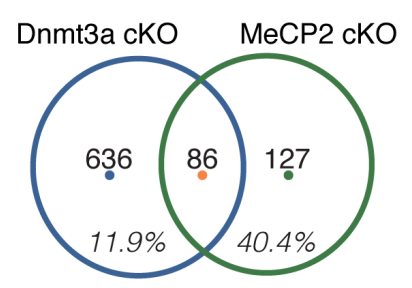

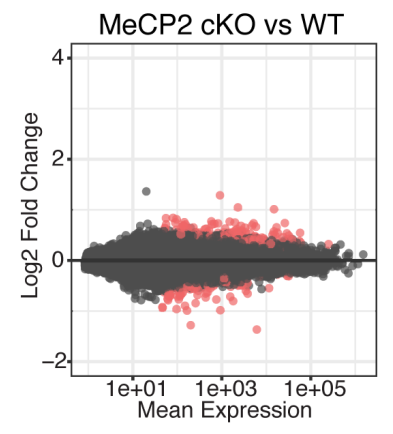

C $\quad$ All DEGs (padj $<0.01)$

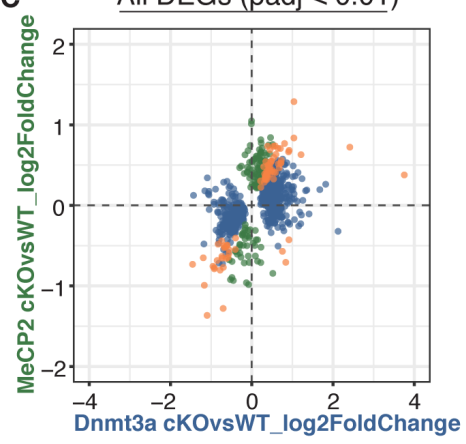

Lavery et al. 
bioRxiv preprint doi: https://doi.org/10.1101/815639; this version posted October 22, 2019. The copyright holder for this preprint (which was not certified by peer review) is the author/funder, who has granted bioRxiv a license to display the preprint in perpetuity. It is made available under aCC-BY-NC-ND 4.0 International license.

Figure 4

DEG Catagories

Lavery et al.

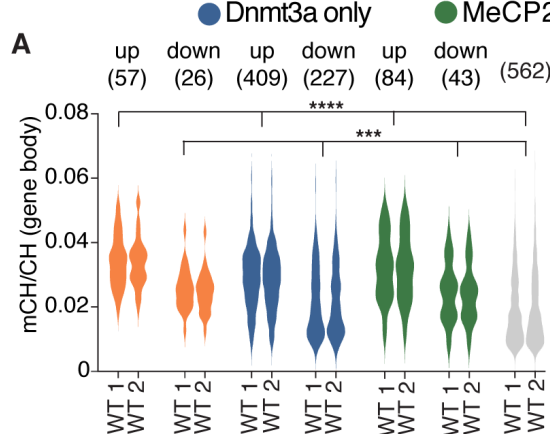

C
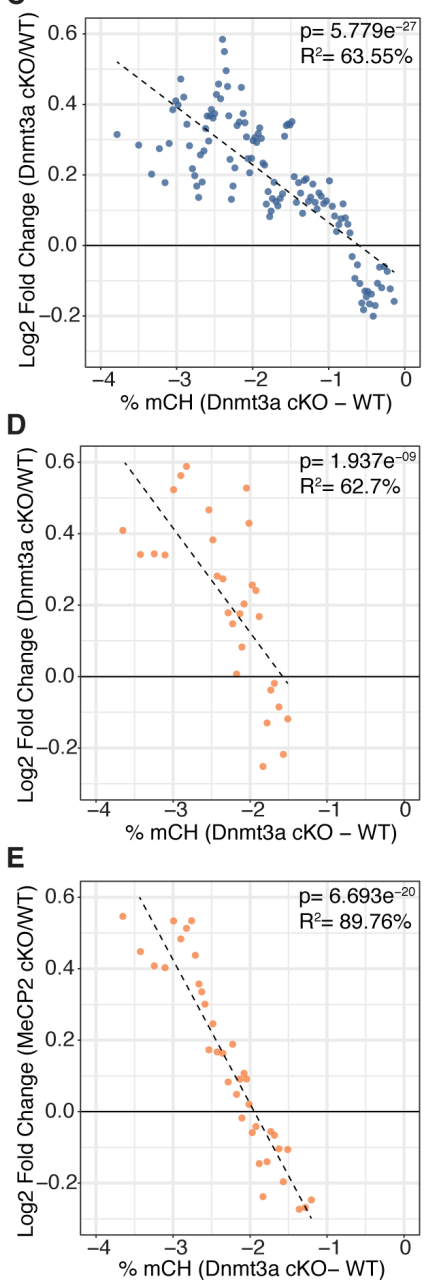

$\mathbf{F}$

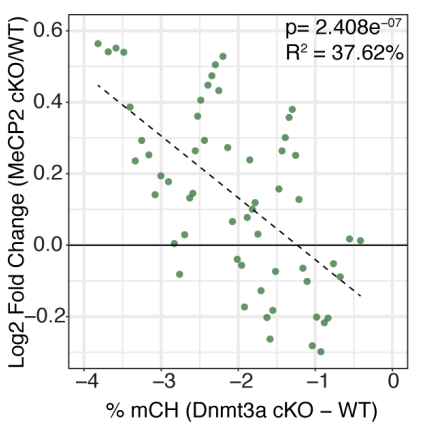

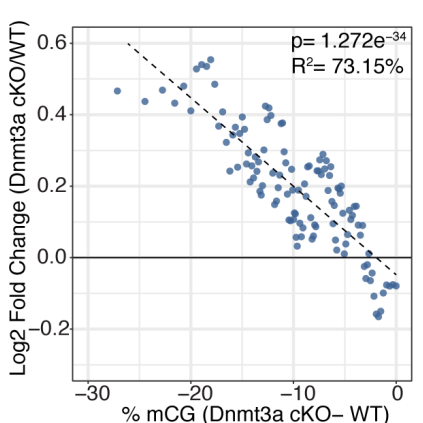
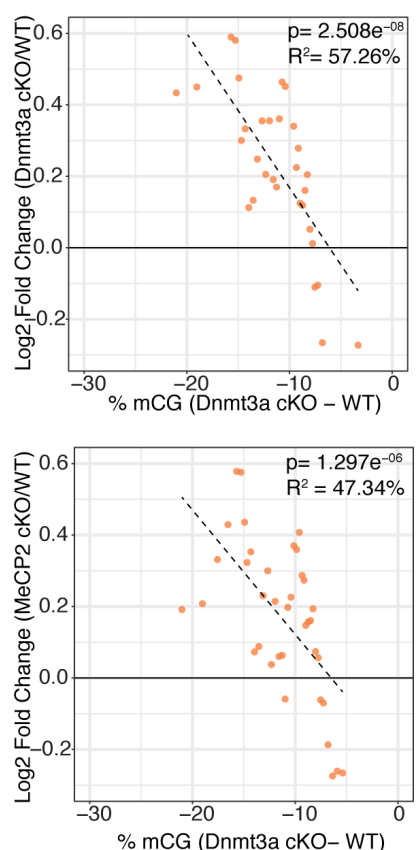

$\%$ mCG (Dnmt3a cKO-WT)

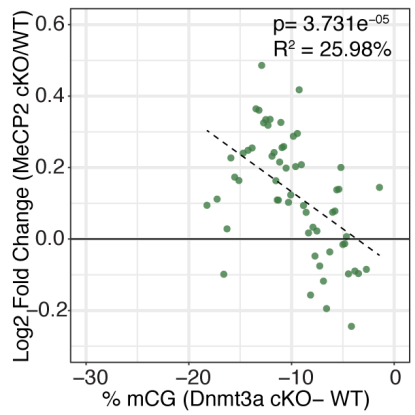

Non-DEG

B up down up down up down

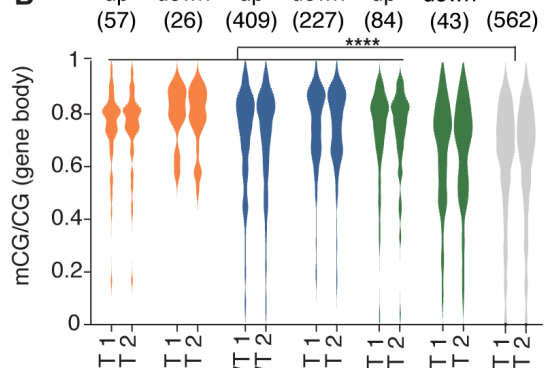

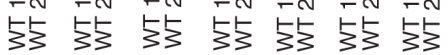

G

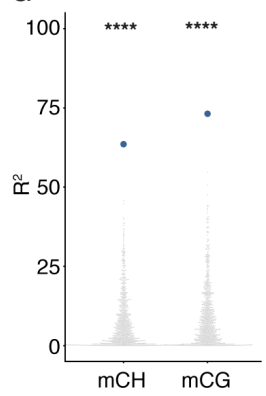

H

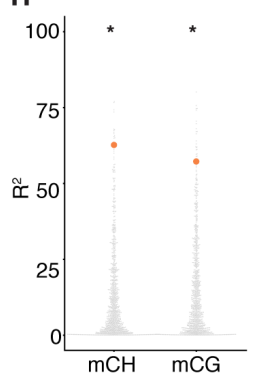

I

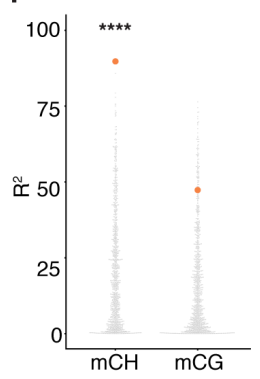

J

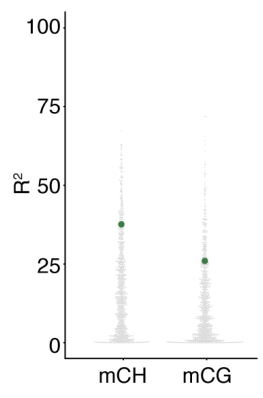


Figure 1. Dnmt3a cKO and Mecp2 cKO mice show overlapping as well as distinct neurological deficits.

A) Mice that lack Dnmt3a or MeCP2 in inhibitory neurons present with hindlimb spasticity. B) Obsessive grooming is increased in both knockout models. C) Nest building, D) grip strength, E) Open Field, F) Fear conditioning tests revealed impairments in both cKO lines. G) Self-injury in Dnmt3a cKO and Mecp 2 cKO mice necessitated humane euthanasia. H) Example traces of miniature inhibitory postsynaptic currents (mIPSCs) recorded in the dorsal striatum. Both cKO models show similar alterations in I) amplitude. J) Weekly body weight records for Dnmt $3 a \mathrm{cKO}$ and Mecp $2 \mathrm{cKO}$ mice showed only Dnmt3a cKO mice (here separated by sex- see Methods) were runted. K) Dnmt3a cKO and Mecp 2 cKO mice showed opposite alterations in acoustic startle response. L) Only Mecp $2 \mathrm{cKO}$ mice displayed impairment on the parallel rod. M) Dnmt3a cKO mice had to undergo earlier euthanasia than Mecp 2 cKO mice due to the severity of their self-lesioning. $n=11-52$ (behavior), $n=5$-9mice per genotype with 24-50 neurons total (electrophysiology). ${ }^{*} p<0.05, * * p<0.01, * * * p<0.001, * * * * p<0.0001$. See Supplemental Table 1 for full statistics.

Table 1. Summary of behavioral and physiological test results in cKO models.

Figure 2. Methylation in striatal inhibitory neurons remains stable without MeCP2, but without Dnmt3a there is global loss of $\mathbf{m C H}$ and some loss of mCG. A) Schematic of INTACT method used to isolate inhibitory neurons from the striata of WT, Dnmt3a cKO, or Mecp $2 \mathrm{cKO}$ mice that also conditionally express the INTACT allele. B) Spearman correlation of methylation profiles from inhibitory neurons sorted from WT vs. Mecp $2 \mathrm{cKO}$ striatum, showing that methylation is stable in the absence of MeCP2. C) Bar graph showing the global $\mathrm{mCH}$ level in each biological replicate (left). Example genes from DNA methylome sequencing tracks showing $\mathrm{mCH}$ signal in two biological replicates per genotype (right). D) Bar graph showing the global $\mathrm{mCG}$ level in each biological replicate (left). Example genes from DNA methylome sequencing tracks showing mCG signal (right). Red bars indicate DMRs. E) Genome wide correlation between $\mathrm{mCH}$ and $\mathrm{mCG}$ in wild-type mice showing poor correlation. F) Genome wide correlation of Dnmt3a dependent $\mathrm{mCG}$ and $\mathrm{mCG}$ (the change in $\mathrm{mCH}$ methylation observed in the Dnmt3a cKO is defined as "Dnmt3a dependent") showing good correlation to indicate that $\mathrm{mCH}$ and $\mathrm{mCG}$ written by Dnmt3a are coupled. Correlation values for $\mathrm{E}$ and $\mathrm{F}$ are Pearson correlations designated as "rho". $n=2$ mice per genotype (see methods for specific genotype information). See Supplemental Table 1 for replicate statistics. 
Figure 3. RNA-seq from sorted striatal inhibitory neurons of WT and cKO mice reveal MeCP2 is a restricted reader for Dnmt3a dependent methylation. A) RNA-seq data of sorted WT vs Dnmt3a cKO or Mecp $2 \mathrm{cKO}$ striatal inhibitory neurons that also express the INTACT allele. Red dots represent genes with altered expression in the knockout cells (padj < 0.01). B) Differentially expressed genes (DEGs) that overlap between knockout models. Inhibitory neurons that lack MeCP2 or Dnmt3a share about 40\% of the same DEGs. Only $\sim 12 \%$ of DEGs in inhibitory neurons that lack Dnmt3a are shared with neurons that lack MeCP2. C) Plot of log2 fold-change for DEGs in Dnmt $3 a \mathrm{cKO}$ and Mecp $2 \mathrm{cKO}$ models. DEGs that are only significantly misregulated in the Dnmt $3 a \mathrm{cKO}$ model, only significantly misregulated in the Mecp 2 cKO model, or common to both models are colored in blue, green, or orange, respectively. The plot shows that the DEGs common to both models have similar degree and direction of change.

\section{Figure 4. Integrative gene expression and methylation analysis shows $\mathrm{mCH}$ and $\mathrm{mCG}$ loss} contribute to Dnmt3a cKO DEGs, and reveals a strong $\mathrm{mCH}$ contribution to RTT A) Gene-body $\mathrm{mCH}$ levels in different categories of DEGs in WT mice are plotted, demonstrating that misregulated genes have higher $\mathrm{mCH}$ than genes that are unchanged. B) Gene-body $\mathrm{mCG}$ levels in different categories of DEGs in WT mice are plotted, demonstrating that misregulated genes (with the exception of MeCP2 down-regulated genes) have higher mCG than genes that are unchanged. C) Running average plot of $\log 2$ fold change in gene expression for genes significantly misregulated only in the Dnmt $3 a$ cKO model versus the change in $\mathrm{mCH}$ methylation observed in the Dnmt3a cKO model ("Dnmt3a dependent $\mathrm{mCH}$ methylation") (left). Running average plot of log2fold change in gene expression for these same genes versus the change in mCG methylation observed in the Dnmt3a cKO ("Dnmt3a dependent mCG methylation") (right). D) Running average plots of log2fold change in gene expression in the Dnmt3a cKO model for genes commonly misregulated in both cKO models versus Dnmt3a dependent mCH (right) and $\mathrm{mCG}$ (left). E) Running average plots of log2fold change in gene expression in the MeCP2 cKO for genes commonly misregulated in both cKO models versus Dnmt3a dependent $\mathrm{mCH}$ (right) and mCG (left). F) Running average plots of log2fold change in gene expression for genes that are only significantly misregulated in the $M e C P 2$ cKO model. G-J) $\mathrm{R}^{2}$ values from analysis in panels C-F shown as blue, orange or green dots, respectively, plotted over 1,000 random repetitions of the analysis with each repetition containing the same number of non-DEGs (padj $>0.01$ ). The results of random repetitions are shown as grey dots. All plots were made with DEGs padj<0.01. $n=2$ mice per genotype for methylation data. $n=4$ mice per genotype (RNA-seq). ${ }^{*} p<0.05$, ${ }^{* *} p<0.01$, ${ }^{* * *} p<0.001$, ${ }^{* * * *} p<0.0001$. 
bioRxiv preprint doi: https://doi.org/10.1101/815639; this version posted October 22, 2019. The copyright holder for this preprint (which was not certified by peer review) is the author/funder, who has granted bioRxiv a license to display the preprint in perpetuity. It is made available under aCC-BY-NC-ND 4.0 International license.

\section{Supplemental Figures and Legends}

\section{Supplemental Figure 1}

A

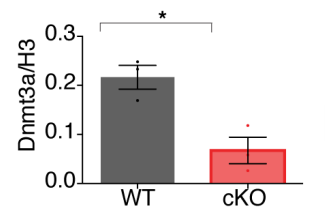

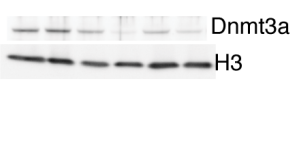

B
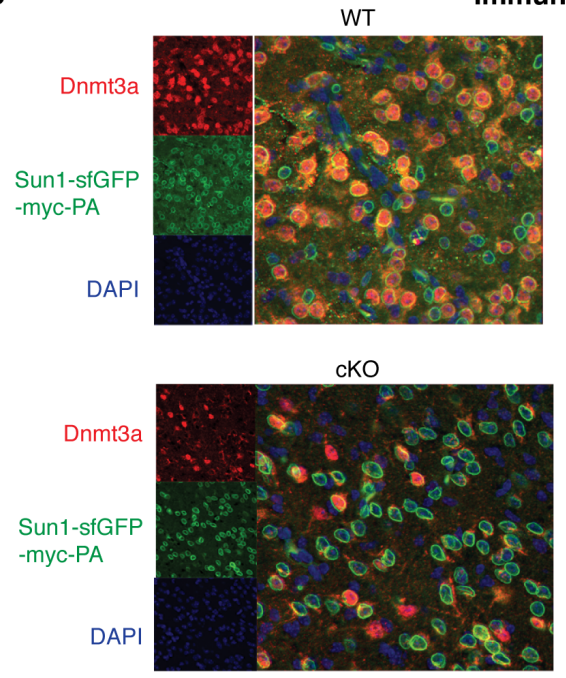

Dnmt3a (2 weeks)
Western
Dnmt3a
$-\mathrm{H} 3$

Western Blots (half brain)

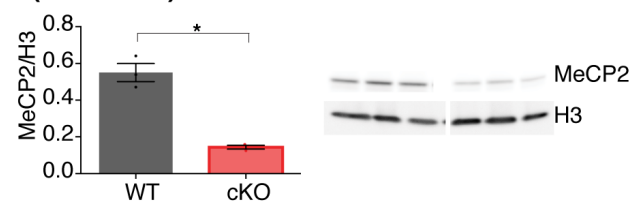

Lavery et al.

Immunofluorescence (midbrain)
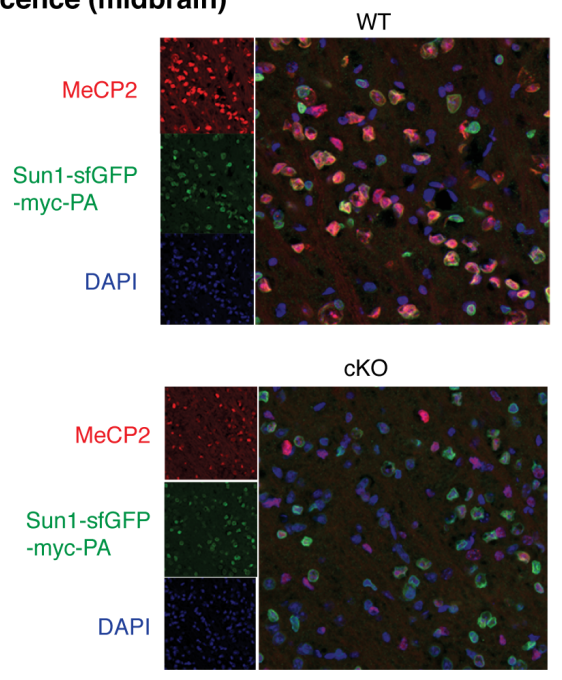

MeCP2 (6-weeks) 
bioRxiv preprint doi: https://doi.org/10.1101/815639; this version posted October 22, 2019. The copyright holder for this preprint (which was not certified by peer review) is the author/funder, who has granted bioRxiv a license to display the preprint in perpetuity. It is made available under aCC-BY-NC-ND 4.0 International license.

Supplemental Figure 2

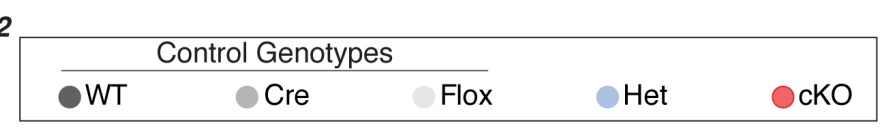

\section{A Open Field (Vertical Activity) B}

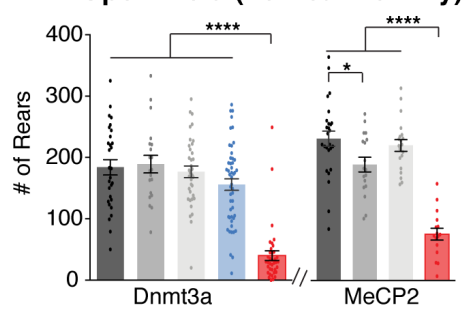

C Fear conditioning (Cue)

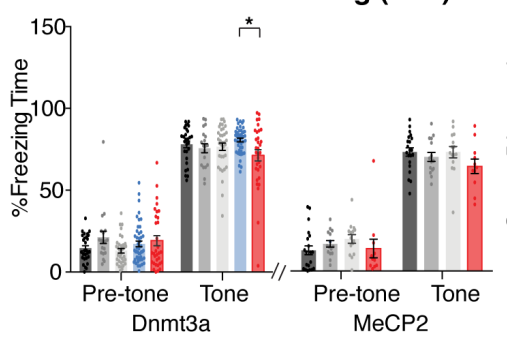

F EPM (distance in open arm)

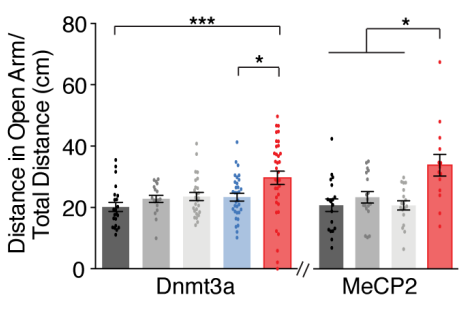

I Rotarod

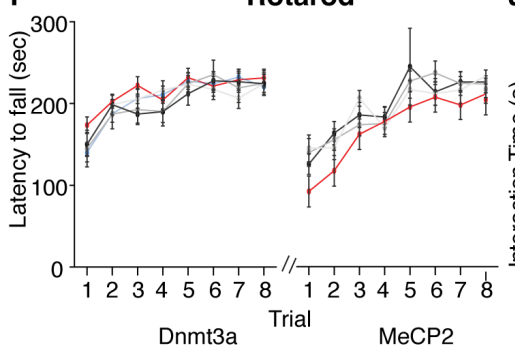

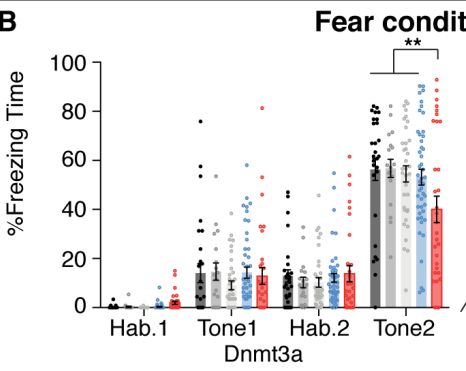

D Open Field (center distance)
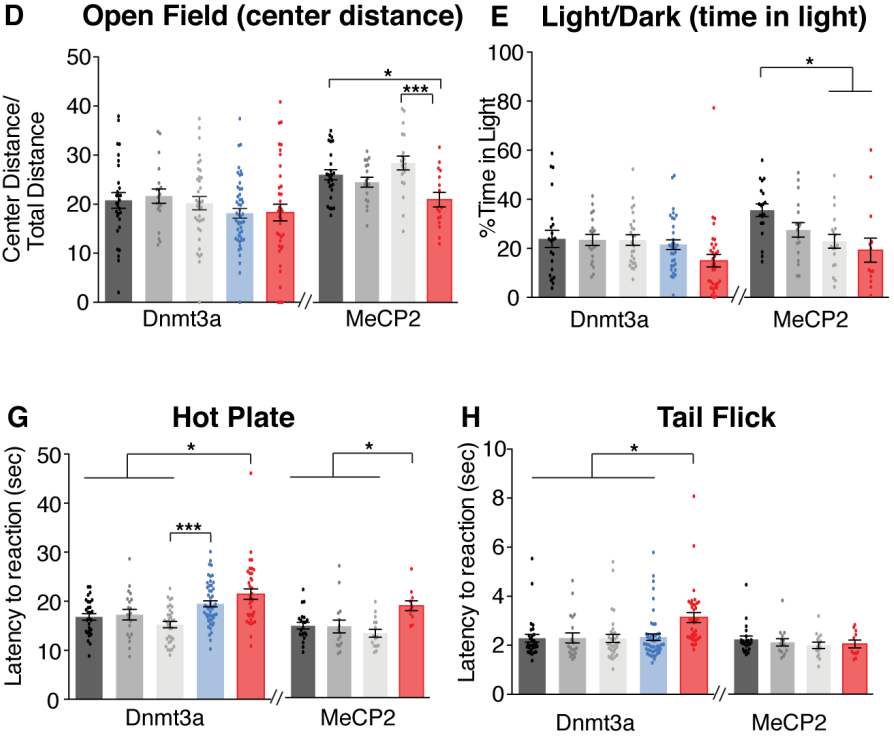

J Partition

K mIPSC (Frequency)
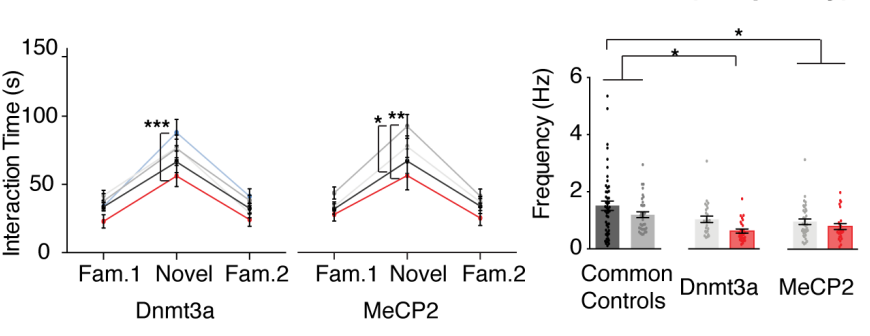

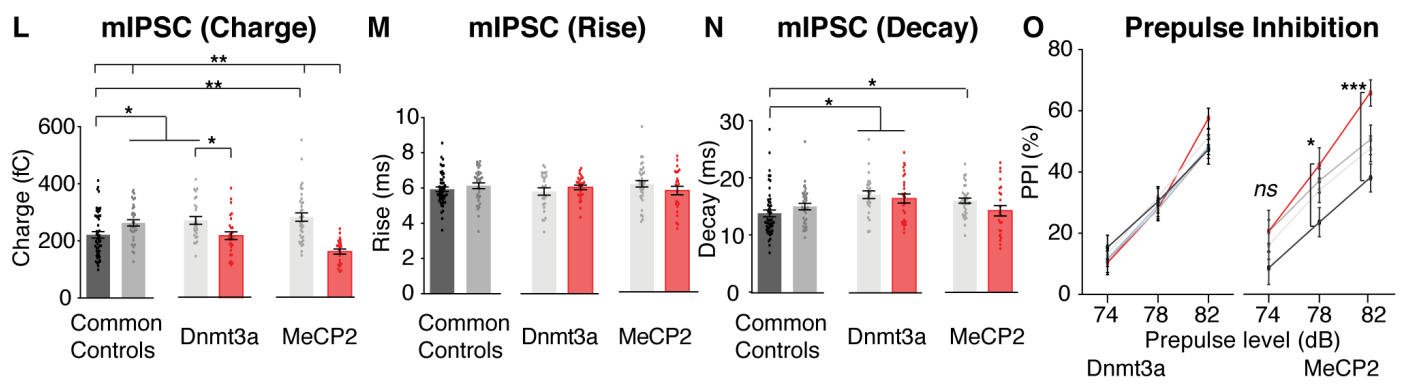


bioRxiv preprint doi: https://doi org/101101/815639. this version posted October 22 2019. The copvriaht holder for this preprint (which was not certified by peer review) is the author/funder, who has granted bioRxiv a license to display the preprint in perpetuity. It is made available under aCC-BY-NC-ND 4.0 International license.

Supplemental Figure 3

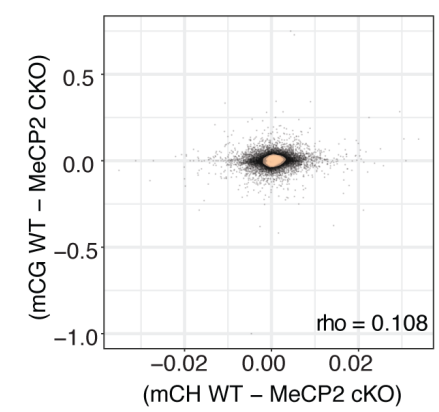

Lavery et al. 
bioRxiv preprint doi: https://doi. org/10.1101/815639; this version posted October 22, 2019. The copyright holder for this preprint (which was not certified by peer review) is the author/funder, who has granted bioRxiv a license to display the preprint in perpetuity. It is made available under aCC-BY-NC-ND 4.0 International license.

\section{Supplemental Figure 4}

A
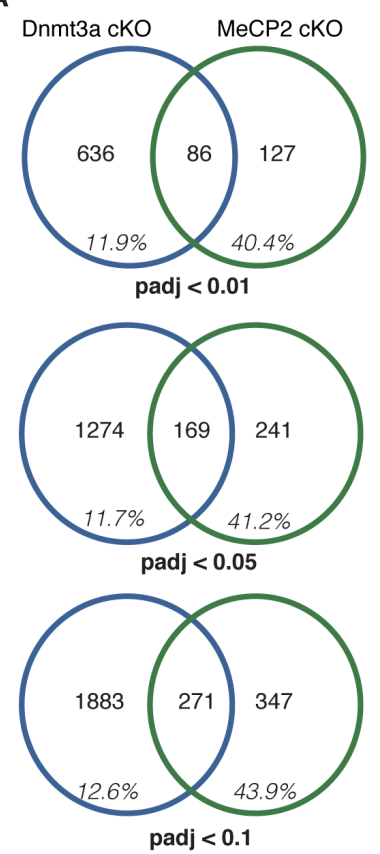

padj $<0.1$
B

Up-regulated genes Dnmt3a cKO

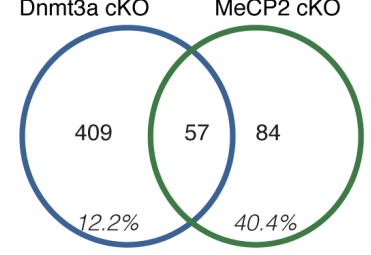

Down-regulated genes

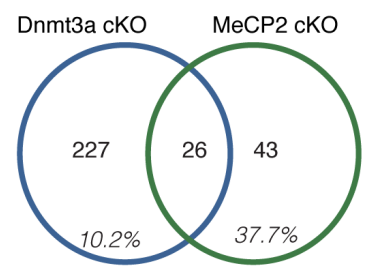

C

Long genes (>100kb)

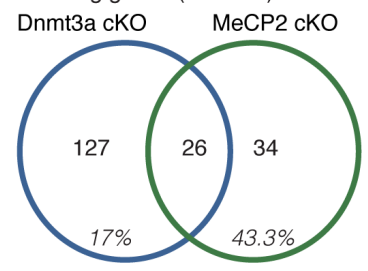

Short genes ( $\leq 100 \mathrm{~kb})$

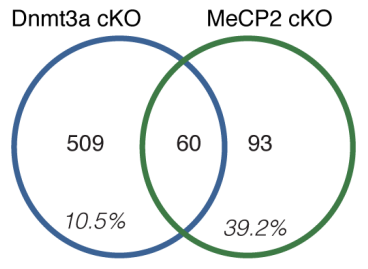

Lavery et al. 
bioRxiv preprint doi: https://doi.org/10.1101/815639; this version posted October 22, 2019. The copyright holder for this preprint (which was not certified by peer review) is the author/funder, who has granted bioRxiv a license to display the preprint in perpetuity. It is made available under aCC-BY-NC-ND 4.0 International license.

Supplemental Figure 5

\begin{tabular}{|l|c|}
\hline \multicolumn{2}{c|}{ DEG Catagories } \\
ODnmt3a Unique OMeCP2 Unique Common Non-DEG
\end{tabular}

Lavery et al.

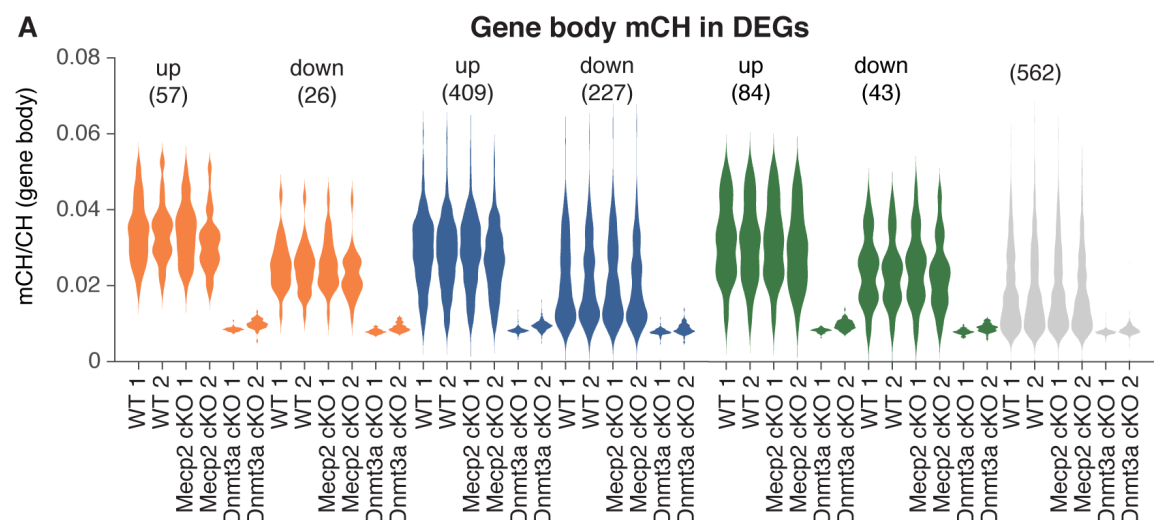

B

Gene body mCG in DEGs

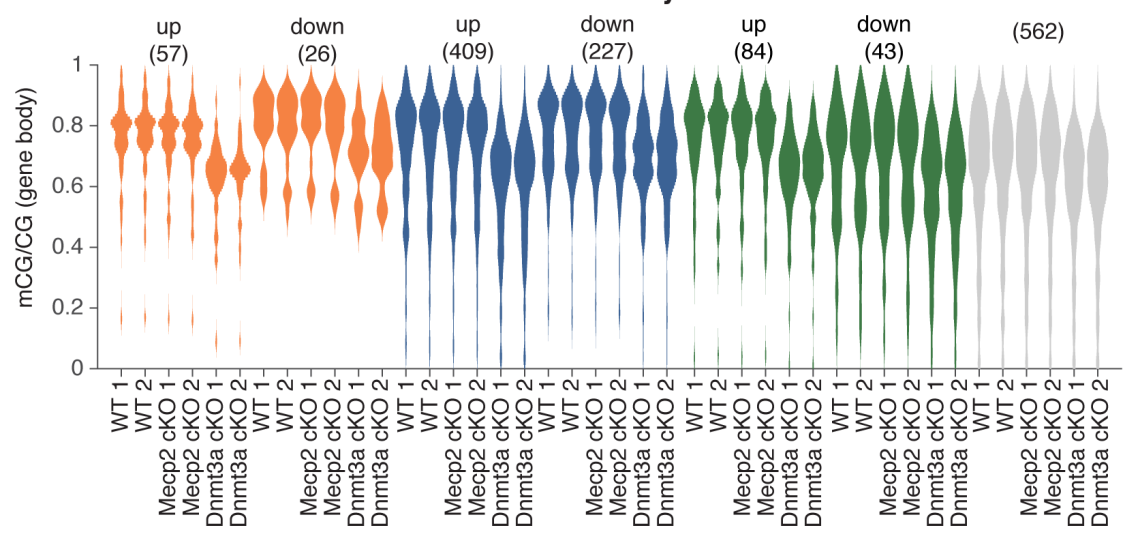

C P-value for gene body $\mathrm{mCH}$ in DEGs (pairwise two-sided ranksum test)

\begin{tabular}{|c|c|c|c|c|c|c|c|c|}
\hline \multirow{2}{*}{ common } & \multirow{2}{*}{$\begin{array}{c}\text { up } \\
\text { (57) } \\
\text { down } \\
\text { (26) }\end{array}$} & $1.0 \mathrm{e}+00$ & $2.6 \mathrm{e}-06$ & $4.1 \mathrm{e}-05$ & $4.6 e-14$ & $1.4 \mathrm{e}-01$ & $2.1 \mathrm{e}-07$ & $5.6 e-20$ \\
\hline & & $2.6 e-06$ & $1.0 \mathrm{e}+00$ & $2.4 \mathrm{e}-02$ & $2.3 e-02$ & $1.7 \mathrm{e}-03$ & $3.8 \mathrm{e}-01$ & $3.2 \mathrm{e}-04$ \\
\hline \multirow{2}{*}{$\begin{array}{c}\text { Dnmt3a cKO } \\
\text { unique }\end{array}$} & \multirow{2}{*}{$\begin{array}{c}\text { up } \\
(409) \\
\text { down } \\
(2777)\end{array}$} & $4.1 \mathrm{e}-05$ & $2.4 \mathrm{e}-02$ & $1.0 e+00$ & $8.5 e-17$ & $.5 e-02$ & $2.6 e-03$ & $4.2 \epsilon$ \\
\hline & & 4.6e-14 & 2.3e-02 & $8.5 e-17$ & $1.0 e+00$ & 2.0e-12 & $5.9 e-02$ & $7.9 e-04$ \\
\hline \multirow{2}{*}{$\begin{array}{c}\text { MeCP2 } \\
\text { unique }\end{array}$} & \multirow{2}{*}{$\begin{array}{c}\text { up } \\
(86) \\
\text { down } \\
(43)\end{array}$} & $1.4 \mathrm{e}-01$ & $1.7 \mathrm{e}-03$ & $1.5 \mathrm{e}-02$ & 12 & +00 & $1.5 \mathrm{e}-04$ & $e-20$ \\
\hline & & 2.1 & $3.8 \mathrm{e}-01$ & $2.6 e-03$ & $5.9 e-02$ & $1.5 \mathrm{e}-04$ & $1.0 \mathrm{e}+00$ & $4.1 \mathrm{e}-04$ \\
\hline \multirow[t]{3}{*}{ Non-DEGs } & \multirow[t]{3}{*}{ (562) - } & $5.6 e-20$ & $3.2 e-04$ & $4.2 e-43$ & $7.9 \mathrm{e}-04$ & $3.8 \mathrm{e}-20$ & $4.1 \mathrm{e}-04$ & $1.0 e+00$ \\
\hline & & up & $\begin{array}{l}\text { down } \\
\text { (26) }\end{array}$ & $\operatorname{up}_{(409)}$ & $\begin{array}{l}\text { down } \\
\text { (277) }\end{array}$ & $\begin{array}{l}\text { up } \\
\text { (86) }\end{array}$ & $\begin{array}{l}\text { down } \\
\text { (43) }\end{array}$ & (562) \\
\hline & & \multicolumn{2}{|c|}{ comm } & $\begin{array}{c}\text { Dnmt? } \\
\text { un }\end{array}$ & & & $\begin{array}{l}\text { cKO } \\
\text { ue }\end{array}$ & Non-DEGs \\
\hline
\end{tabular}

D P-value for gene body mCG in DEGs (pairwise two-sided ranksum test)

\begin{tabular}{|c|c|c|c|c|c|c|c|c|}
\hline \multirow{3}{*}{ common } & \multirow{3}{*}{$\begin{array}{c}\text { up } \\
(57) \\
\text { down } \\
\text { (26) } \\
\text { up }\end{array}$} & $1.0 e+00$ & $9.6 e-02$ & $3.2 \mathrm{e}-01$ & $6.8 e-01$ & $8.2 e-01$ & $2.2 e-02$ & $2.7 e-05$ \\
\hline & & $9.6 e-02$ & $1.0 e+00$ & $2.2 \mathrm{e}-02$ & $2.5 e-01$ & $1.2 e-01$ & $3.0 e-03$ & $4.5 e-05$ \\
\hline & & $3.2 e-01$ & $2.2 e-02$ & $1.0 e+00$ & $8.9 e-03$ & $2.1 \mathrm{e}-01$ & $9.5 e-02$ & $4.6 e-08$ \\
\hline \multirow[t]{2}{*}{$\begin{array}{c}\text { Dnmt3a cKO } \\
\text { unique }\end{array}$} & $\begin{array}{l}\text { (409) } \\
\text { down- }\end{array}$ & $6.8 e-01$ & $2.5 e-01$ & $8.9 e-03$ & $1.0 e+00$ & $6.4 \mathrm{e}-01$ & $3.7 e-03$ & $3.7 e-13$ \\
\hline & up & $8.2 e-01$ & $1.2 e-01$ & $2.1 e-01$ & $6.4 e-01$ & $1.0 e+00$ & $1.8 e-02$ & $1.8 e-06$ \\
\hline \multirow[t]{2}{*}{$\begin{array}{c}\text { MeCP2 } \\
\text { unique }\end{array}$} & down- & 2.2e-02 & $3.0 e-03$ & $9.5 e-02$ & $3.7 e-03$ & $1.8 \mathrm{e}-02$ & $1.0 e+00$ & $5.9 e-01$ \\
\hline & $\begin{array}{c}(43) \\
(562)\end{array}$ & $2.7 e-05$ & $4.5 e-05$ & $4.6 e-08$ & $3.7 e-13$ & $1.8 e-06$ & $5.9 e-01$ & $1.0 e+00$ \\
\hline \multirow{2}{*}{ Non-DEGs } & & up $_{(57)}$ & $\begin{array}{l}\text { down } \\
(26)\end{array}$ & $\begin{array}{c}\text { up } \\
(409)\end{array}$ & $\begin{array}{l}\text { down } \\
(277)\end{array}$ & $\operatorname{up}_{(86)}$ & $\begin{array}{c}\text { down } \\
(43)\end{array}$ & \multirow{2}{*}{$\begin{array}{c}(562) \\
\text { Non-DEG }\end{array}$} \\
\hline & & \multicolumn{2}{|c|}{ common } & $\begin{array}{r}\text { Dnmt } \\
\text { un }\end{array}$ & & \multicolumn{2}{|c|}{$\begin{array}{c}\text { MeCP2 cKO } \\
\text { unique }\end{array}$} & \\
\hline
\end{tabular}


bioRxiv preprint doi: https://doi.org/10.1101/815639; this version posted October 22, 2019. The copyright holder for this preprint (which was not certified by peer review) is the author/funder, who has granted bioRxiv a license to display the preprint in perpetuity. It is made available under aCC-BY-NC-ND 4.0 International license.

Supplemental Figure 6

A All genes

Dnmt3a cKO MeCP2 KO

PV

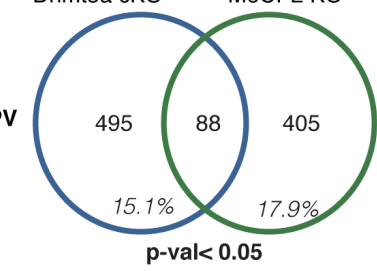

B

B All genes

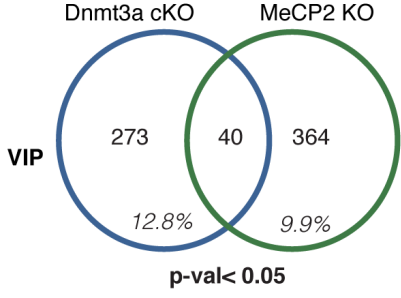

Up-regulated genes

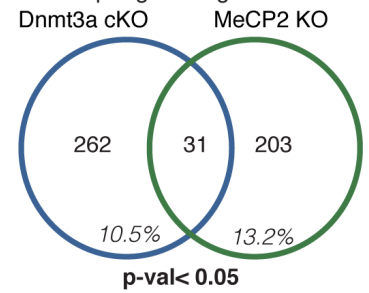

Up-regulated genes

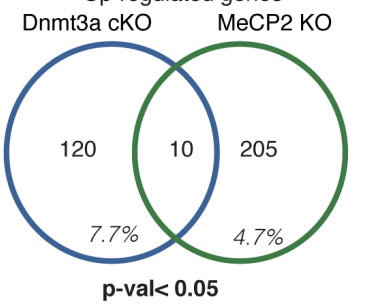

Lavery et al.

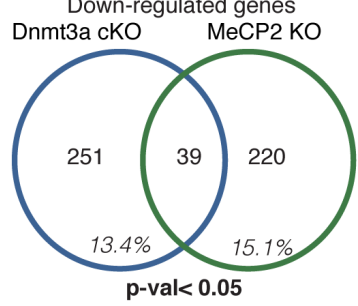

Down-regulated genes

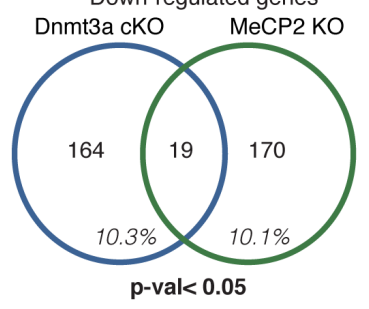


Supplemental Figure 1. A) Western blot of half brain hemisphere from Dnmt3a or Mecp $2 \mathrm{cKO}$ mice demonstrating appropriate loss of each protein. B) Immunofluorescence (IF) images of WT, Dnmt3a cKO or Mecp2 cKO mice probing for Dnmt3a or MeCP2 (red), the Sun1-sfGFP-myc-PA fusion protein that marks the nuclear envelope and is dependent on Cre expression (green), and DAPI to mark genomic DNA (blue). $n=3$ mice per genotype (western), $n=3$ mice (IF) representative image shown.

Supplemental Figure 2. A) Both mouse lines showed decreased rearing in the Open Field test. B) Dnmt3a cKO mice showed impaired fear learning, whereas Mecp 2 cKO mice did not differ from control mice. C) Cue memory was normal in both cKO mice. D-F) Tests for anxiety-like behaviors (open field, light dark or elevated plus maze, respectively). G) Hot plate and $\mathbf{H}$ ) tail flick testing for nociceptive pain in both cKO mice. I) Rotarod test for motor learning and coordination and $\mathbf{J}$ ) the partition test for social interaction. K-N) Frequency, rise and decay measures from mIPSCs from the striatum. O) Only Mecp2 $\mathrm{cKO}$ had a trend for increased pre-pulse inhibition. $\mathrm{n}=11-50$ per genotype (behavior), $\mathrm{n}=5-9$ mice per genotype with 24-50 neurons total (electrophysiology), ${ }^{*} \mathrm{p}<0.05,{ }^{*} \mathrm{p}<0.01, * * * \mathrm{p}<0.001,{ }^{*} * * * \mathrm{p}<0.0001$. See Supplemental Table 1 for full numbers and statistics.

Supplemental Figure 3. Plot of the difference in genome wide $\mathrm{mCH}$ versus $\mathrm{mCG}$ methylation between the $\mathrm{WT}$ and $\mathrm{MeCP} 2 \mathrm{cKO}$ mice. Person correlation designated as rho. Consistent with stable methylation in the absence of $\mathrm{MeCP} 2$, the differences center at 0 .

Supplemental Figure 4. The percentage of DEGs that overlap between cKO mouse models broken down as a function of $\mathbf{A})$ p-value, B) direction of change (down- or up-regulated), C) gene length.

Supplemental Figure 5. A) Gene-body $\mathrm{mCH}$ levels in different categories of DEGs in WT, Dnmt3a cKO and Mecp 2 cKO mice. B) Gene-body mCG levels in different categories of DEGs in WT, Dnmt3a cKO and Mecp 2 cKO mice. C) P-value matrix for comparison of $\mathrm{mCH}$ levels of different categories of genes illustrating significant differences versus non-DEGs. The boxes are colored such that more significant $\mathrm{p}$ values are darker shades of red. D) P-value matrix for comparison of mCG levels of different categories of genes illustrating significant differences versus non-DEGs. As in C, the boxes are colored such that more significant $p$-values are darker shades of red.

Supplemental Figure 6. The percentage of DEGs that overlap between parvalbumin (PV) and vasoactive intestinal polypeptide (VIP) neurons in the mouse cortex from Dnmt $3 a \mathrm{cKO}$ (Nestin-Cre) and Mecp2 KO 
mouse models. The data are a re-analysis of single-nuclear RNA sequencing (19). The percentages are shown as all genes and genes broken down by direction of change (down- or up-regulated) for A) PV and B) VIP neurons. Consistent with our data there are few DEGs significantly misregulated in Dnmt3a cKO mice that are also significantly misregulated in the same neurons that lack MeCP2. Notably, our data show a significantly higher overlap of genes (40\%) misregualted in Mecp $2 \mathrm{cKO}$ that are also misregulated in the Dnmt $3 a$ cKO.

Supplemental Table 1. Numbers and statistics for all mouse behavioral assays and methylation datasets.

Supplemental Table 2. RNA-seq data and DEGs used in figures.

Supplemental Movie 1. Forepaw stereotypies are apparent in Dnmt3a cKO mice. Video shows an example of forepaw stereotypies in a Dnmt3a cKO male mouse at 8-week of age. 